\title{
Bravery in the Delicate: An Actor's Exploration of Thea Elvsted in Henrik Ibsen's Hedda Gabler
}

\author{
Mary Catherine Goff \\ mcg0022@mix.wvu.edu
}

Follow this and additional works at: https://researchrepository.wvu.edu/etd

Part of the Theatre and Performance Studies Commons

\section{Recommended Citation}

Goff, Mary Catherine, "Bravery in the Delicate: An Actor's Exploration of Thea Elvsted in Henrik Ibsen's Hedda Gabler" (2021). Graduate Theses, Dissertations, and Problem Reports. 8098.

https://researchrepository.wvu.edu/etd/8098

This Thesis is protected by copyright and/or related rights. It has been brought to you by the The Research Repository @ WVU with permission from the rights-holder(s). You are free to use this Thesis in any way that is permitted by the copyright and related rights legislation that applies to your use. For other uses you must obtain permission from the rights-holder(s) directly, unless additional rights are indicated by a Creative Commons license in the record and/ or on the work itself. This Thesis has been accepted for inclusion in WVU Graduate Theses, Dissertations, and Problem Reports collection by an authorized administrator of The Research Repository @ WVU. For more information, please contact researchrepository@mail.wvu.edu. 
Bravery in the Delicate:

An Actor's Exploration of Thea Elvsted in Henrik Ibsen's Hedda Gabler

\author{
Mary C. Goff \\ Thesis submitted \\ to the College of Creative Arts \\ at West Virginia University \\ in partial fulfillment of the requirements for the degree of \\ Master of Fine Arts in \\ Acting
}

Radhica Ganapathy, Ph.D., Chair

Brianne Taylor, M.F.A.

Jessica Morgan, M.F.A.

Lee Blair, M.F.A.

School of Theatre and Dance

Morgantown, West Virginia

2021

Keywords: Thea Elvsted, character development, Hedda Gabler, Henrik Ibsen, Catherine Fitzmaurice, Acting, Realism, Free Associative Journaling, Cynthia Bassham

Copyright 2021 Mary C. Goff 


\title{
ABSTRACT \\ Bravery in the Delicate: \\ An Actor's Exploration of Thea Elvsted in Henrik Ibsen's Hedda Gabler
}

\begin{abstract}
Mary C. Goff
"It was not really my desire to deal in this play with so-called problems. What I principally wanted to do was to depict human beings, human emotions, and human destinies, upon a groundwork of certain of the social conditions and principles of the present day."

-Henrik Ibsen, The Correspondence of Henrik Ibsen

This purpose of this document is twofold: to examine the process of character creation over the course of my experiences performing the role of Thea Elvsted in West Virginia University's spring 2020 production of Henrik Ibsen's Hedda Gabler, and to define Thea's dramatic significance to Hedda Gabler as a whole. The following text will provide a detailed look at the research I collected in the interest of building a cohesive view of the world of the play. Additionally, it will describe the various techniques I employed throughout the rehearsal and performance process of the production, with specific attention paid to my usage of Fitzmaurice Voicework ${ }^{\circledR}$, Meisner, and Stanislavski. To conclude, I will offer a post-production evaluation of the performance experience and a retrospective analysis of the rehearsal process.
\end{abstract}




\section{ACKNOWLEDGEMENTS}

I would like to extend my deep gratitude to the members of my committee. To Dr. Radhica Ganapathy, thesis chair extraordinaire: your encouragement has been unfaltering, and from the conception of this document to its final form you have been my most constant ally and mentor. To Brianne Taylor: thank you for introducing me to the world of Fitzmaurice Voicework ${ }^{\circledR}$. Your guidance over the past three years has revolutionized the way my voice lives in me, both as an artist and as a person. To Lee Blair and Jessica Morgan: thank you for your insight, grace, and support through this process. I am honored to call you mentors and soon-to-be colleagues.

I would also like to acknowledge the faculty and staff of West Virginia University, especially Cathy O’Dell, Cornel Gabara, Jerry McGonigle, and Josh Williamson, for their influence on the artist I have become over my three years of study. To R.J. Nestor, who has taught me so much about my voice and myself in these past few years: thank you for your wisdom and your friendship, and for always prodding me forward. To Robynn Rodriguez: thank you for allowing me the room to explore this character, whose story has been told so many times, with new eyes. And to the members of my cohort: what a strange and beautiful journey we've taken over the past three years. Thank you for your camaraderie, resilience, and persistence. We're almost there.

I am forever indebted to my family, who have been my biggest champions. To my fiancé, Ndil-Adjim Sou Ngadoy: you are my muse, my inspiration, and my ever-present cheerleader. Thank you for always encouraging me to see in myself the things that you see in me. You are, and always will be, mon âme soeur. To my parents, Jan Goff, Anne Johnson, and Lee Johnson: even in moments when you have not fully understood this bizarre business that I have thrown myself into, you have always supported my journey through it. And to my brothers, Brian Goff and Joey Reynolds: words cannot express how much your love and your goofball antics have kept me sane on a daily basis.

This document would not exist today with the support of the many professors who have spanned my academic career. To Sean Boyd, Louis Rackoff, Craig Dettman, Harry Waters Jr., Patrick Gendusa, Stephen Judd, Dr. John Warrick, Monica Hayes, and Robin Aronson: a hearty thanks for your investment in me as a student and an artist.

And finally, to Kate Riley, whose guidance all those years ago made me believe in the integrity of my own artistic voice: thank you for starting me on this long and winding path. With each step I take, I think of you.

"I can no other answer make but thanks, and thanks; and ever thanks..."

-William Shakespeare, Twelfth Night 


\section{TABLE OF CONTENTS}

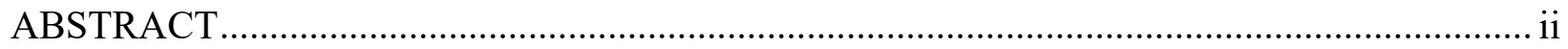

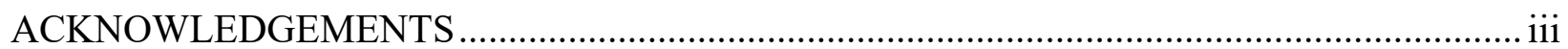

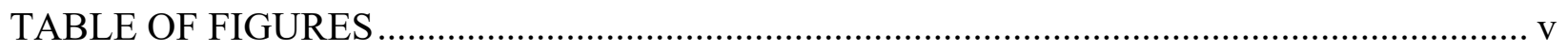

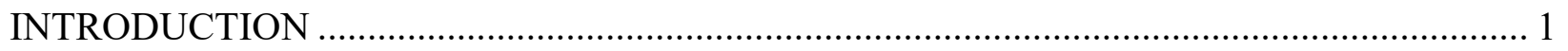

CHAPTER ONE: Historical Framework ......................................................................... 7

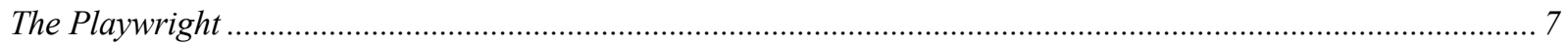

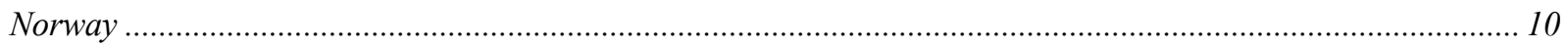

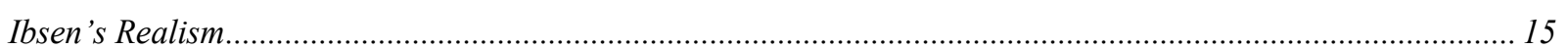

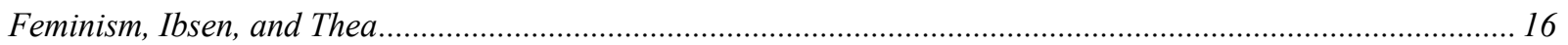

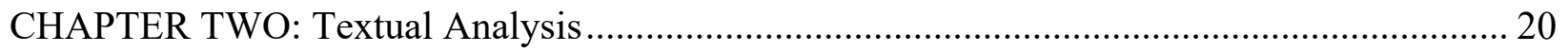

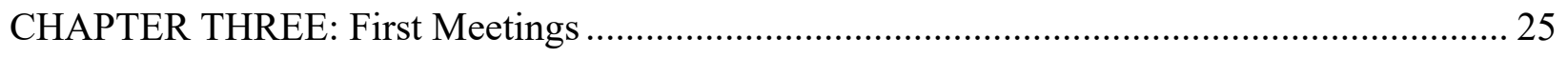

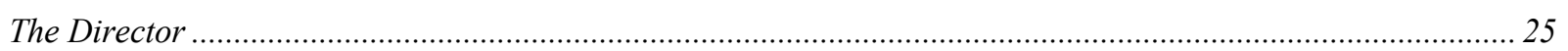

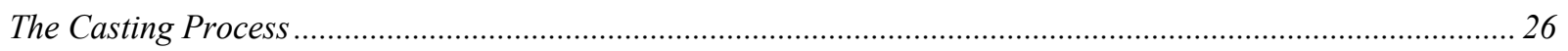

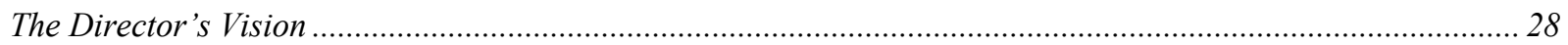

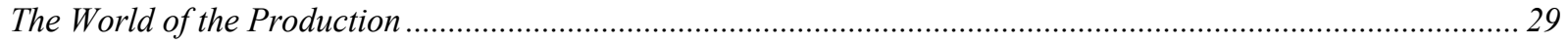

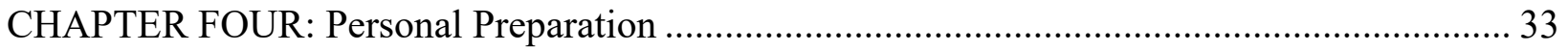

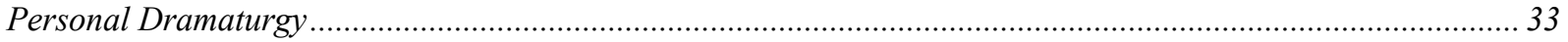

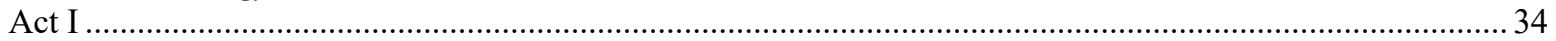

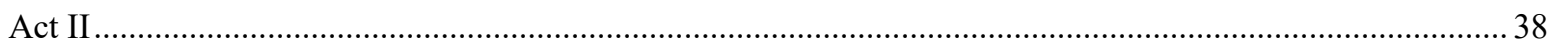

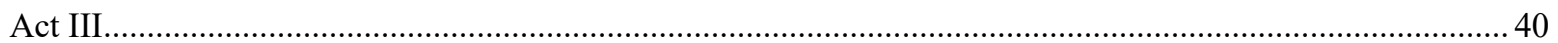

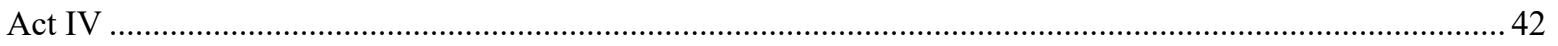

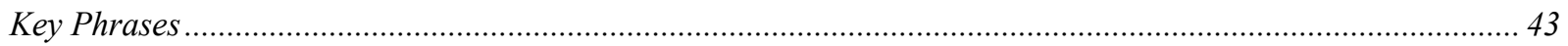

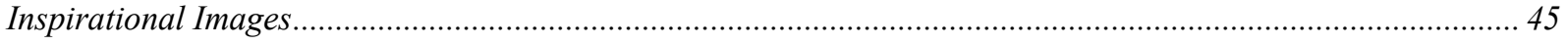

CHAPTER FIVE: Methodology of Character Development ................................................. 53

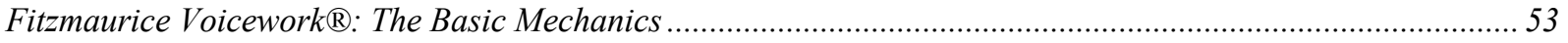

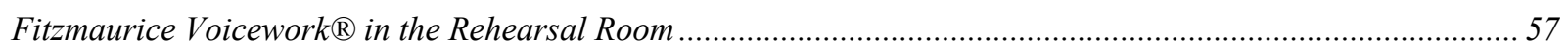

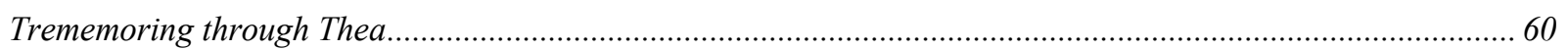

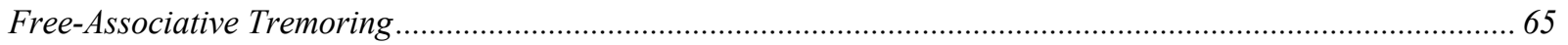

CHAPTER SIX: FORMING THE PARTS INTO A WHOLE ............................................. 69

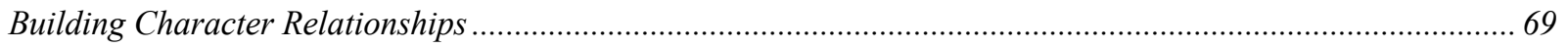

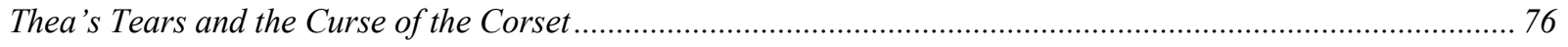

Conversations with the Director ............................................................................................................. 79

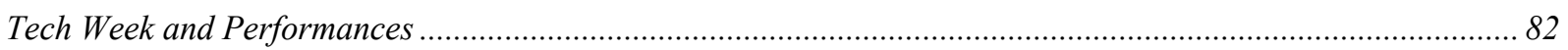

CONCLUSION: DECONSTRUCTING PROCESS .......................................................... 85 


\section{TABLE OF FIGURES}

Fig. 1: Backer, Harriet. By Lamplight. 1890. Oil on canvas. The Eclectic Light Company,. https://eclecticlight.co/2016/05/11/into-the-light-harriet-backer-inside-and-out-2/. Accessed 19 Feb 2021.

Fig. 2: Ancher, Anna. Sunlight in the Blue Room. 1891. Oil on canvas. Skagens Kunstmuseer, https://skagenskunstmuseer.dk/en/works/sunlight-blue-room/. Accessed 19 Feb 2021.

Fig. 3: Gericault, Theodore. Portrait d'Alfred et Elisabeth Dedreux. 1818. Oil on canvas. Christie's, https:/www.christies.com/lot/lot-theodore-gericault-rouen-1791-1824-paris5157401/?. Accessed 19 Feb 2021.

Fig. 4: Rothko, Mark. Untitled (Black on Gray). 1969-1970. Acrylic on Canvas Guggenheim, https://www.guggenheim.org/artwork/3535. Accessed 19 Feb 2021.

Fig. 5: No author. No title. 2017. Photograph. Pxhere.com, https://pxhere.com/en/photo/1212440. Accessed 19 Feb 2021.

Fig. 6: Barer, Cara. Explorer. 2011. Archival pigment pring on rag paper. The Week, https://theweek.com/captured/459676/carving-art-literature. Accessed 19 Feb 2021.

Fig. 7: No author. Mundal Hotel. ca. 1890-1910. Photograph. The Nordic Page, https:/www.tnp.no/norway/multimedia/4646-11-historical-photos-from-norway-that-makeyou-surprized. Accessed 19 Feb 2021.

Fig. 8: Waider, Jan Erik. Fleeting Moments of Autumn: Fjord Norway. No date. Photograph. Northlandscapes, https://www.northlandscapes.com/portfolio/norway-fleeting-moments-ofautumn. Accessed 19 Feb 2021. 


\section{INTRODUCTION}

The process of writing this thesis was, to say the least, unorthodox. In many graduate programs the actor begins research on their thesis role immediately after casting, or even before, if they are assigned a role prior to the usual casting process. Then come the first reads, the staging rehearsals, and the scene-work and run-throughs that allow the play's ensemble time to coalesce their discoveries into a unified narrative. Finally, after some amount of time that feels like a small eternity yet is always slightly too short, opening night arrives, and the cast is free to live and breathe in the world of the play for a few precious hours each night of the run, until the production closes. All of a sudden, the show is over, the set is struck, and the actor must gather their notes and begin compiling them into something coherent and vaguely intelligent so they can have some record of just what they've been doing for their three-odd years of training. In any other year this might have been the way rehearsals progressed for my thesis performance, but since our production took place in 2020, we were practically fated to do things out of order. Which was how I found myself leafing through my first pages of research on Thea Elvsted from Hedda Gabler, my chosen thesis role, four months after the production closed.

I'd initially had my eye on Thea or Hedda as possible thesis contenders prior to casting, though I had to audition and cross my fingers that the casting assignments would work in my favor since WVU's graduate acting program did not pre-cast their graduate actors. Like most who approach the play, I was initially drawn to Hedda. Her mercurial nature and her tangled relationships to the other characters fascinated me, as did the flashy ideal of playing the title character in what I imagined as the penultimate casting of my graduate career. I paid little attention to Thea, registering her as soft, delicate, and interesting but not, well, fascinating enough. Important, but not deserving of the top billing. Hedda captivates, then combusts. Thea exists, then 
presumably continues to exist after the curtain drops. My mind only began to turn in Thea's favor during callbacks, when I heard the director, Robynn Rodriguez, give the note to another actor that "Thea is the bravest woman in all Norway." The comment was simple yet groundbreaking, and it forced me to check my assumptions of Thea. Brave? Brave and delicate. Brave and soft. Brave in that she persists within her circumstances, even as others succumb to the pressure. This was captivating in its own right. So when the cast list was announced and my name appeared on the line next to Thea Elvsted, I felt a thrill of excitement that far outweighed the petty twinge of missing out of playing the elusive, seductive Hedda Gabler. Thea had her own mysteries for me to unpack, and I was ready to get started.

The casting assignment did not guarantee that I would be able to use my work on Thea for my thesis, and I had some initial concerns that the graduate program would reject my proposal. Our production of Hedda Gabler fell in the spring of our graduate class's second year, which technically made any role we were assigned that semester fair game for thesis material. As casting for Hedda Gabler drew closer, however, some key faculty members' tenor shifted. Yes, we could use a role in Hedda Gabler, but only certain roles. Hedda for sure, and maybe one or two of the men's roles, since they were deemed significant in size and value to the story. There was no mention of Thea. Overall, the graduate students were strongly encouraged to submit proposals for the fall production of King Lear, which fell in our third year. Shortly after casting I wrote a small and passionate essay in defense of Thea that elaborated on my desire to investigate her through a feminist lens, and after some discussion between the faculty I was approved. Rehearsals were already underway by this point, so I moved from tentatively bookmarking articles on Ibsen and the world of Norway in the 1890s to voraciously reserving library books and downloading content from the library's databases. I quickly realized that I would not have time to balance rehearsals, 
my coursework, my assistantship, and develop dramaturgy for the role of Thea. Unfortunately, my in-rehearsal research would need to be confined to the answering of immediate questions that arose from the play's given circumstances, and any deep-diving into the nature of Thea's theatrical significance would have to wait until post-production. I remember being so tired during the week of performances that I only vaguely registered the news stories breaking the news of a respiratory flu that was spreading like wildfire through China and parts of Europe. The cast squeaked through our closing weekend days before COVID-19 caused a nation-wide shutdown. We spent the remainder of our semester doing the seemingly impossible task of converting to online theatre classes. After finals week I was convinced I would never want to look at a computer screen again. I went to my father's home in Mississippi and tried not to think about the looming death of an industry that I had spent my entire life trying to gain entry to, until I regained enough energy to kick myself for procrastinating on thesis research. So, I dusted off my notes taken during the rehearsal process and the books I had picked up just before the shutdown and began searching for information on Thea.

As it turns out, not much research existed that specifically discussed Thea. Usually, articles that dissected the feminism of Ibsen's late works devoted most of their attention to Hedda, and Thea was rarely even mentioned. Even extended analyses of the play turned up little information specific to Thea. I finally stumbled across a volume that contained Ibsen's work notes from an early draft of Hedda Gabler, and as I leafed through it, I noticed several mentions of Thea's name. Aha! Success at last, and from the very source who created her. I greedily scanned the text for any reference to Thea in hopes of gleaning some insight to her origins.

By this time, I had lived with Thea for almost half a year. I had rehearsed as her, performed as her, and now I was trying to fill in the details that would academically confirm her value to the 
story of Hedda Gabler. To borrow a description that I heard from our director, Robynn Rodriguez, Thea was "the bravest woman in Norway," and through my thesis I would examine this bravery that I had begun to think was grossly overlooked by academics and theatre-makers alike. As I unwound her story in rehearsal, I had developed an image of Thea as a quotidian activist who subtly propelled gender parity even as everyone in her environment underestimated her. She had left her husband, played a crucial role in drafting a groundbreaking manuscript, and helped a friend struggling with addiction to find sobriety and stability. Surely Ibsen's notes would yield some confirmation of her importance. Perhaps he had based her on his adoring sister Hedvig, who had been described as "a woman of delicate, warm feelings and much strength of character" and who strove to understand the poetic genius of her brother, much like Thea strove to understand Eilert (Morison 5). Or perhaps a real-life Thea passed through Ibsen's world only briefly, a friend or acquaintance whose outward delicacy belied inner strength and determination. I skimmed the pages of Ibsen's notes until I came to the first full sentence that mentioned Thea by name.

"Thea Elvsted is the conventional, sentimental, hysterical Philistine" (Cole 161). I stared at the page. This couldn't be right. I continued to read in hopes that perhaps this note was a fluke from some scribbled rough draft and that Ibsen self-corrected later on, yet every mention of Thea brought new waves of shock.

"Nervous-hysterical modern individual" (157).

"Harmless" (164).

"Weak"

"Soft"

"Frightened" (167). 
I kept rereading in hopes that I had missed something. A lengthy footnote early in the passage gaily described how more notes had been saved from Ibsen's drafts of Hedda Gabler than any of his other works. At no point did the playwright describe Thea as having a single redeeming quality. I glumly closed the book and considered this clash between my expectations and this unwelcome realization that Thea Elvsted was diminutive even in the eyes of her own playwright.

As I moped, I reflected back on the rehearsal process: conversations with a committee member where we had discussed the challenges of pasting a contemporary feminist label on a character who predated the term's modern usage, Robynn's insistence on Thea's strength and resilience, moments where Robynn directed me to ignore stage directions that called for Thea to act flighty or nervous or terrified with little to no build-up in the text. I began to recognize that those adjustments had saved me from playing Thea as the harmless, weak, and nervous-hysterical woman who haunted Ibsen's notes. The more I pondered Thea's trajectory in her text, however, the more I bridled at the insinuation that Thea could be solely defined by any of these base descriptors. For all her self-effacing words and soft-spoken ways, Thea acts with courage. She leaves home in pursuit of a greater purpose with someone she loves, and for all her delicacy, she manages to persevere through the loss of her greatest friend. She is the one who forms the idea to compile Eilert's notes into a new manuscript after he destroys the first. She is the one who survives through the end of the play.

With this in mind, I began to hatch a new plan: I would mine the play's text for evidence of Thea's worth. My thesis would catalogue my interpretations of her character, discoveries made in rehearsal, techniques I used to build her character, and a dramaturgical examination of her context and origins. Through a textual analysis of the script, a breakdown of both the production's methodology and my personal approach to unpacking Thea's character, and a retrospective 
analysis of rehearsals and performances I would provide a framework both for the greater world of the play and Thea's function within it. By the end, with any luck, I would reinforce Thea's complexity and illuminate the magnitude of her necessity to the play she inhabits. 


\section{CHAPTER ONE: Historical Framework}

Before delving into the details of the production and the rehearsal process we must establish the historical lens through which we can view the story. Ibsen's texts are notoriously spare and strategic in their use of language, so it is of the utmost importance to have a thorough understanding of his own world and the context in which he was writing Hedda Gabler to better understand his possible motivations in crafting the play, the characters, and their dialogue as he did. ${ }^{1}$

\section{The Playwright}

Henrik Ibsen was born in 1828 in Skein, Norway, a remote lumber town south of Christiania. His father, a general store owner, was forced to declare bankruptcy when Ibsen was a young child, and Ibsen himself left school at the age of fifteen to become an apprentice to an apothecary in the nearby town of Grimstad (Gray 1422). While there he became romantically involved with a maid in his master's household, and she gave birth to a son. Although he did not participate in the child's upbringing, his son's birth is theorized to have fueled Ibsen's interest in illegitimacy, a theme which surfaced later in his dramatic works (1422).

Six years after beginning his apprenticeship, Ibsen moved to the capital in hopes of studying at the University of Christiania, but he failed the entrance exams and never finished his studies. He did, however, befriend several political radicals who, like Ibsen, were spurred by the revolutionary spirit that had begun to sweep through Europe following political uprisings across the continent (1422). Ibsen aspired at this time to become a poet, and in fact got himself into a fair

1 The following research was completed post-production during my deconstruction and analysis of the rehearsal process, and the information presented here is unique from the information provided in the production dramaturg's table work with the cast. For details on the production dramaturgy, see "Chapter Three: Methodology." 
amount of hot water in Grimstad by writing comic poems that lampooned the town's upper-crust citizens (Morison 6). In describing his experiences in Grimstad, Ibsen wrote of it as a "little provincial town, where it was impossible for me to give expression to all that fermented in me except by mad, riotous pranks" (198). During his tenure there Ibsen wrote his debut play Catalina, whose 1850 publication marked both Ibsen's transition to playwrighting and the beginning of the end of his time in Grimstad (7). He was commissioned as both a playwright and director of the newly formed Norwegian Theatre in Bergen just one year later, a career shift which catapulted him from obscure poet to leader of a nationally recognized theatre company (Van der Poll 84).

Although Ibsen's literary and dramatic voice was highly passionate, as a young person he cut a timid figure (Gray 1423). As he became further immersed in his work with the Norwegian Theatre he was left with little time to write, which affected his self-confidence. Additionally, under his tenure the theatre was plagued with economic difficulties; though Ibsen attempted to gear his writing and the theatre's programming towards Norwegian patriotism and was at times wellreceived by audiences, his work failed to achieve the critical support necessary for financial success (Van der Poll 84).

In 1862 the Norwegian Theatre failed, and Ibsen sought respite from overwork and his financial woes by petitioning the government for an annual salary as a cultural ambassador to Norway. He was rejected and instead offered a travel scholarship that enabled him to travel to Italy in 1864 (85). Two years later he became the recipient of an annual grant for writing that provided consistent funding during his time abroad. He spent the next 27 years of his career living between Italy, Germany, and France. During this time he wrote some of his most celebrated works, the verse plays Brand and Peer Gynt. These two distinctly Norwegian and highly poetic plays brought him international success (Gray 1423-1424). 
Ibsen abandoned verse forms in the early 1870 s and instead began to cultivate a dramatic voice that featured simpler, more accessible language that both replicated natural speech patterns and proved easier to translate from Norwegian than his previous works (1444). However, Ibsen's intention to communicate "the illusion of reality" in his newly austere form of writing should not be mistaken for a lack of poetry; critics have been quick to point out that rather than abandoning poetic forms, Ibsen recreated them in conversational language (1426). The mundanity of his plays' dialogue spoke to the collision of science and drama as Realism and Naturalism came to the theatrical forefront. Psychology, photo-realistic depictions of daily life, and a sense of objective observation began to overtake the archetypes of Victorian melodrama, and the poetic language of the theatre shifted away from the florid verse of yesteryear and towards this modern paradigm of linguistic austerity (Cardullo and Knopf 20). This period in his writing saw the publication of Pillars of Society, Ghosts, and A Doll's House.

Ibsen published Hedda Gabler in 1890 and premiered in January of 1891 at the Residenz Theatre in Munich. Productions across Scandinavia and other cities in Germany soon followed, including a production at the Christiania Theatre that Ibsen attended upon his return to Norway in August of 1891. The play proved immensely popular, and productions opened across the European continent, in Australia, and eventually in New York with the British originator of Hedda, Elizabeth Robins, reprising her turn in the title role (Archer 9-10).

By this time Ibsen was well-established as an international celebrity. James Joyce, Henry James, and George Bernard Shaw were among his admirers, with all three writers publishing articles or books that spoke to his dramatic achievements (Gray 1436). Critics have since theorized that Ibsen's reluctance to declare himself on one side of any issue could have been an influential aspect of his popularity, in that audiences and artists have been free to interpret the playwright's, 
and, by extension, his characters', motives (Van der Poll 87-88). In an interesting example of his pointedly noncommittal nature, Ibsen never declared Nora as the feminist icon that women's rights activists claimed her to be, nor did he position himself as a champion of women's liberation (1421). Dramatists and critics have similarly wrestled with Ibsen's placement within the dramatic canon; while in today's context he is commonly noted as a founder of realist drama, symbolist dramatist Maurice Maeterlink claimed Ibsen as a fellow symbolist and Shaw titled him a "dramatist of ideas" (Gassner xiii), while Swedish critic Edvard Alkman credited him under both the realist and naturalist schools of thought (Van der Poll 88). Whatever the case may have been according to Ibsen, by the time he settled back in Norway after his 27-year hiatus abroad he was immensely popular and wealthy. 1898 saw his $70^{\text {th }}$ birthday and the peak of his professional career $(100-101)$. In 1900 Ibsen suffered a stroke that effectively ended his writing career. He lived out his final years in Christiania and died in 1906, leaving behind him a legacy of dramatic works that continue to draw modern audiences into conversations about social norms and gender roles (Hacht 829).

\section{Norway}

Norway's political and national identity shifted dramatically within Ibsen's lifetime. The country had been under the rule of the Danish monarchy from the 1300 s until after the Napoleonic wars. While under Danish rule, Copenhagen functioned as the cultural and political capital of the two nations, and the Norwegian language slowly began to erode from official usage in governing and aristocratic circles in favor of Danish. Following the Napoleonic wars in 1814 Denmark was required to transfer the rule of Norway to Sweden (Van der Poll 82-83). Norway attempted to declare independence from Sweden later that same year and established its own democratic constitution and parliament. Norwegian independence did not last, however, and in a matter of months Sweden regained political control of Norway. The Norwegians agreed to submit to 
Swedish rule if they were able to retain their parliament and function within a union with Sweden rather than as a conquered territory. Thus, the two nations forged a truce, and Norway largely retained its political autonomy while submitting to Swedish rule (Bryden et al. 45-46).

This transition of power opened the door for Norway to reclaim its sense of national identity after centuries of Danish influence. Over the nineteenth century the Norwegian language, primarily preserved in rural areas during the time of Danish rule, became the language of choice for writers and intellectuals, and dramatists such as Bjørnstjerne Bjørnson and Ibsen began to produce dramas and poetry that specifically catered to elements of Norwegian culture (Van der Poll 83). Notably, the theatre company that Ibsen ran in the early portion of his career, Det Norske Theatre, was founded on this very notion of reinforcing Norwegian cultural identity, and Ibsen was selected to run the company on the basis of articles he had previously written in defense of Norwegian nationhood (84).

As Norway developed a political voice the country began to reform its political and social systems away from those put in place by the monarchic Denmark and towards a more populistdriven, egalitarian ideal. In 1837, in a move to decentralize the Norwegian government, rural areas were divided into municipalities with locally elected governments (Bryden et al. 98). The nobility was formally abolished in 1821 , and while in the first half of the century the country was primarily run by a contingent of university-educated state officials and theologians, in 1884 the establishment of multi-party parliamentarianism paved the way for more diverse representatives to enter the political sphere (Skirbekk 20-21). The structure of educational systems also shifted during this time. Compulsory elementary schooling existed in Norway as early as 1739, and by 1848 Norway required that all children in both rural and urban areas, regardless of social status, attend a communal school (Lauglo 269). Over the latter half of the century Norwegian schools 
began to drop subjects such as Latin and Greek, which were seen as contrary to Norwegian identity, and incorporate modern languages into their curriculum (270). Even religion felt the effects of the changing political tide. Under the Danes, Norway had been an established Lutheran nation whose people participated in the church out of formal obligation (Bryden et al. 189). In 1814 the Norwegians furthered the church's political platform by including a Secretary of Ecclesiastical Affairs in their Cabinet. The formation of local governments in 1837 further reinforced the influence of the church by asserting the influence of local congregations over nearby schools and welfare systems (196). The 1884 introduction of parliamentarianism, however, diffused the power of the clergy by allowing increasingly secular political parties to form. By 1889 the clergy had lost a significant amount of its foothold in schools, and civil servants were no longer required to maintain membership in the church (197).

1884 similarly proved a pivotal year for Norwegian women's rights. At this time women were denied the right to vote, and only some 40 percent of the male population that owned property qualified for voting rights (159). The Norwegian female political voice emerged with the formation of Scandinavia's first society for women's suffrage (100). Women were also officially permitted to attend Norway's sole university in Christiania starting in 1884, inclusive of all degrees, courses, and scholarship opportunities (Maddison 154). Despite these apparent advancements, Norway lagged behind its neighboring countries, in that Norwegian women were not entitled to equal pay, nor were married women permitted any control over their own property as Swedish and Danish women were (Collett 191-193). Camilla Collett, a prolific Norwegian writer and leader in the Scandinavian feminist movement, wrote extensively on women's treatment as second-class citizens in a rapidly modernizing Norwegian society, with specific attention to the established scientific "fact" that women were incapable of rational thought due to their biological role in 
childbearing (Ørjasæter 23). In an 1884 essay Collett described Norway’s sluggishness to adopt feminist policies as a product of the nation's relative newness: “... as yet, she has not had the might nor the time to test all the questions, and to solve all the problems... Hence it is that all which concerns woman and women's place in society has lingered pretty much in its former state" (Collett 196). In Collett's view, women were both emotive and intellectually equal to men. However, women were dealt a two-fold blow: their intellectualism was suppressed by patriarchal social systems, and they were conditioned into repressing their emotions, which conflicted directly with the socialized message that a woman's first priority is to love and nurture her family (Ørjæster 26). To leverage her argument for equality, Collett drew inspiration from French revolutionaries who pointed to motherhood and childrearing as a social contribution, and therefore an inherently political act. Thus, she asserted, in the interest of being better equipped to raise their children to be productive future citizens, women deserved the ability to educate and financially support themselves equally to men (27). It bears mentioning that Collett's ideologies had a strong impact on Ibsen's work. The two writers shared a warm friendship, and their bond prompted Ibsen to reconsider his previously conservative views on gender and sex as he delved further into his playwrighting career (19). Collett is credited with inspiring Ibsen's A Doll's House, which extensively investigates feminine agency and confinement within the socially dictated roles of marriage and motherhood, and the women of each of Ibsen's subsequent plays bear the distinct echoes of Collett's essays and writings (20).

While education had increasingly become a communally accessible and valued aspect of Norwegian society, female educators existed in a social limbo that often rendered them outcasts. The Victorian convention of the governess clung on in families who were affluent enough to afford them, and the existence of a governess in the household indicated that the woman of the house was 
a lady of leisure who could delegate the menial tasks of domesticity and childrearing to others (Peterson 9). The governesses themselves, however, enjoyed little social advantage from their position, as they navigated the duality of being well-bred and educated, yet still a servant within the household who would often be tasked with tending to the children long after lessons were done for the day (14). Additionally, a governess bore the scarlet letter of being a "working woman" who demeaned herself by accepting money in exchange for labor, which subverted the expectation that women should strive towards leisurely inoccupation (10). Once a woman had fallen to the level of accepting paying work as a governess, she was destined to live halfway between the roles of servant, family member, and educator, until she was able to suitably marry her way out of the dilemma of her employment (20).

Even as Norway advanced politically and socially, it remained a fairly rural country. During the time in which Ibsen was writing Hedda Gabler only a quarter of Norway's population would have lived in a major city (Bryden et al. 127). Amidst this period of political and social transition, the industrial revolution was making its way onto Norwegian soil. Factory-based industries began to appear towards the middle of the century (124). Unlike other countries, where factories developed primarily in urban areas and consequently drew a large percentage of the population into the cities, Norway's industrialization remained largely dispersed through its rural communities where the raw materials for industrial labor were more easily accessible. Citizens of rural Norway often lived in subsistence households and survived by growing at least some of their own crops and livestock (126). Plans for a Norwegian rail system began in the 1840s and allowed greater access to Norway's inland regions, beginning with the Trunk Railway in 1854 that connected Christiania to Eidsvoll (Dahlmann). Though railways expedited travel, the trips still proved long and arduous. A train voyage from Trondheim, one of the largest major cities in 
northern Norway at the time, to Christiania would have taken two days, with an overnight stay in the middle of the trip at Tynset or Koppang ("The Rørosbanen Railway").

\section{Ibsen's Realism}

Ibsen is often credited as the father of Realism, but to understand what this means we need to establish a working definition of realism as a theatrical style. The term "realism" is often applied flexibly to connote a sense of real life reflected onstage and is frequently interchanged with its cousin, naturalism. In the interest of clarity, we can look to a definition furnished by writer and critic Raymond Williams, who states that the historical movement of Realism has three key identifiers: a connection to secular rationalism, a foothold in actions rooted in the present, and a broad representation of social experience (Lacey 68). Whereas its predecessor, melodrama, focuses on the intervention of external, often supernatural forces on its characters, realism expounds upon the internal and pragmatic struggles of daily life (Gilmour 345). A Realist playwright of Ibsen's day sought to bring the mundanity of the contemporary middle class to the stage to witness their experiences on an immediate and human level.

Historians and critics are quick to label Ibsen a realist dramatist, and even throughout his lifetime he was claimed by naturalist, symbolist, and realist theatre critics and dramatists by turns. The ambiguity surrounding his true affiliation perhaps stems from the fact that, despite the opinions of his colleagues, Ibsen never declared himself as a member of any one school of thought (Van der Poll 88). While most of his works can easily be categorized as realist dramas based on the criteria above, it would be reductive to ignore the influences that Victorian melodrama had on many of his later works. A Doll's House, for example, arguably contains several stock characters from melodrama in its representation of Torvald as an uncompromising moralist and of Nora as the self-sacrificing wife who is torn to pieces by a benevolent lie (Gray 1428). The play evades 
being reduced to a melodramatic narrative not by entirely avoiding associations with the genre but by turning these images on their head. The sweet-faced wife, caught in her supposed sin and faced with the possibility of never seeing her children again, quits the narrative entirely and slams the door behind her. Hedda Gabler was written over a decade later and focuses even more wholly on the quotidian details of its characters, so the traces of melodrama are much fainter, but still present. Thea Elvsted's past as a governess who marries into the family after the wife's tragic end could practically be an homage to Jane Eyre, until she reveals that the marriage was one of convenience rather than love and has left her isolated in a remote Norwegian village, living in a role she wears in name but does not feel comfortable fully inhabiting. Once again, Ibsen subverts the archetype, and any potential echoes of romanticism are peeled away to make room for the ordinary.

\section{Feminism, Ibsen, and Thea}

Another unsettled question that is often prescribed an answer by theatre historians and critics: is Ibsen a feminist writer? Though he was famously quoted as speaking in defense of women's rights on several occasions, the playwright swore off the label of feminism under the claim that he was supporting all of society's disenfranchised members, inclusive of women ("Ibsen and Feminism" 89). His protests against the label did little to dissuade women's rights activists, however, and they readily accepted his creation of Nora Helmer as an overt sign of his support for the movement (Gray 1429). Ever since he has frequently become posthumously recognized as a uniquely feminist voice within the genre of early modern realism, although one can imagine given his apparent distaste for aligning with any particular group that were he still living he would have a few things to say about this categorization.

Thus, we are left to ask a follow-up question: is it accurate to the narrative of his plays to interpret Ibsen's works through a feminist lens of the time? In turning an eye towards Hedda 
Gabler, the answer feels most obviously to be yes. The women within are all tasked in some way with the burden or joy of maternity; Miss Tesman is described by Tesman as a simultaneous mother and father figure and seems to readily accept the comment as praise, while Thea and Hedda each are tasked with caring for children to whom they feel little to no personal attachment. Although she demurely protests claiming her husband's children as her own, Thea passionately describes Eilert's manuscript, their mutual life's work, as her own child. The contemporary feminist might be frustrated by the continual references to women existing as mothers in the play, but rather than dismissing women as only existing to nurture men and their children Ibsen seems to be pointing out that few other options would have been open to them at the time. He plops these women into the circumstances of 1890 s Norwegian reality and allows the women to live in those roles as human beings. Do they joyfully welcome the concept with open arms, as Miss Tesman does with her nephew? Deliberate with impending dread on an unwelcome pregnancy, as with Hedda? Or reject maternity in one form in favor of recreating the sense of family altogether, as Thea does with Eilert? All three characters point to the fact that in putting these women onstage Ibsen is commenting on their conditions and asking the audience to draw their own conclusions.

All this is not to say that Ibsen's commentary on women's issues is flawless. Turning an eye back to Ibsen's notes on early drafts of Hedda Gabler, we begin to see some chinks in the ideological armor lent to him by historians:

The feminine imagination is not active and independently creative like the masculine. It needs a bit of reality as a help (Cole 160).

Or to return to his descriptions of Thea in those same notes:

Mrs. Elvsted: weak build. The eyes round, rather prominent, almost as blue as water. Weak face with soft features. Nervous gestures, frightened expression-(167). 
One could argue that these represent early versions of the characters that are not necessarily reflected in the finished script, until observing the stage directions in that very script:

Gives her a frightened look, and says quickly (Ibsen and Turner 16).

Pleadingly (18).

Frightened (18).

Alarmed (19).

Staring blankly and helplessly (21).

Throughout the play Ibsen prescribes fearfulness, tears, and anxiety to Thea over and over, leaving the actor who follows his stage directions to the letter with little choice but to present a prototypical "damsel in distress." Further investigation of this phenomenon unveils that one academic has gone so far as to typecast many of Ibsen's women into two groups: the femme fatale and the darling. These two characters nearly always oppose each other with a man in between functioning as the crux of their conflict. One, typically the leader of the pair, presents an image of rebellious contrarianism, while the other, the docile image of feminine gentleness, meekly flits in and out of the background (Hossain 2).

With this, the question persists: can we in good conscience say that Ibsen's women are feminist representations? Or are they reductive, limited by the narrow view of their creator who needed his ladies to march through the script to a specific cadence in order to get to the end on time? Ultimately, both arguments have merit. The women that Ibsen put onstage were singular in many ways, chiefly in that he rarely demanded that they be likeable. Hedda is free to explore the demonic side of her middle-class ennui, and Thea is able to sob her way through scene after scene with Ibsen's blessing. Simultaneously, the artist can take a frank look at the script and its stage directions and understand that any theatrical performance is, at its heart, collaborative. To fully 
explore a narrative one must embody it, flaws and all, but the actor who is invited to step into the world of the Tesman living room does so with the understanding that their responsibility is to tell the story within the context of the production's interpretation. The Thea Elvsted of Ibsen's invention might have trembled constantly as she navigated the world, but the Thea that would be brought to life in our production did not necessarily need to be beholden to the sole interpretation of a playwright whose life ended some 115 years ago. Thea is nervous, anxious and concerned for her friend's welfare, and gullible to Hedda's influence, but exactly how that should and could be realized onstage would be determined by hours of rehearsal and reflection. Unlike the words of a century-old script, these decisions had yet to be born. 


\section{CHAPTER TWO: Textual Analysis}

This chapter will outline one of the most essential pre-production steps for anyone with creative influence within a production: text analysis. Performing a close reading of the script is of paramount importance for any play and especially so for an Ibsen work, where so much of the information concerning character and story lie hidden beneath the surface layers of the dialogue. Analyzing the text allows the actor to begin to ponder questions and ideas that can be explored in rehearsals concerning the play's thematic elements, given circumstances, and character relationships. Additionally, these initial readings help the actor to begin synthesizing any early research or dramaturgy with their understanding of the text, so that they are better able to peer at the world of the play through any relevant historical, social, or personal lens applied by the playwright.

At its core, Hedda Gabler is the story of a woman caught in stagnation in the midst of a rapidly shifting world: one which is as pointedly secular, austere, and at times dispassionate and cold as its titular character. While larger political machinations are never overtly mentioned in the play, we can see the traces of Ibsen's Norway, a country that was just starting to assert its identity, direction, and purpose, in the living room of the Tesman household. The house is newly purchased to celebrate a marriage yet is isolated from the bustle of high society on the suburban fringes of the capital and reeks of the death of its last inhabitants. Meanwhile, the union that precipitated the house's purchase lacks passion or affection, with one member comfortable in their developing routine of married life and the other chafing at the confinement of settling for the middle-class. This is the stasis in which George Tesman thrives and Hedda Gabler smothers.

It must be noted, however, that this is not a play of ideas. We are presented with a living room drama, in the truest sense of the word. The central action never pulls the audience's gaze into 
another room of the house or towards the world beyond; instead, spectators are asked to reckon with a room that is at once private and public, intimate in size yet expansive in who is welcomed into it. In this microcosm of daily life, we bear witness to the characters as people rather than symbols. Their language sounds ordinary, sparse, and subtextual, and their motivations are consequently not always immediately clear. No one who enters the living room is purely classified as a hero or villain; they all act selfishly in some way and bear qualities that are paradoxically admirable and unpleasant.

A central point of this narrative are two women who largely exist in direct opposition. Hedda is the last of a dying class of aristocratic ladies of leisure. She is regal, exacting, manipulative, and capable of navigating the transition from coy warmth to icy cynicism in the span of a breath. Above all, she is fixed in place within the house, and once she enters it she is destined to never again leave. Conversely, Thea Elvsted emerges from murky, middle class origins as a working woman turned lady of the house by virtue of marriage. Where Hedda is dark, she is light: Ibsen even goes so far as to stipulate that the women contrast physically in his descriptions of Hedda as having hair that is "a handsome medium brown, but... not especially abundant" while Thea is described as blue-eyed and in possession of fair hair that is "exceptionally wavy and abundant" (Ibsen and Turner 9, 15). Where Hedda is hard and inaccessible, she is delicate, gentle, warm, and feminine. She is self-effacing and an optimist, and her circumstances have forced her to seek opportunities in the interest of her continued survival. When comparing Thea's delicacy and timorousness to Hedda's steely tenacity, it's a wonder that the two women ended up in situations so diametrically opposed to their temperaments. Even Thea's history with George as a high school sweetheart and her willingness to trust the people around her as immediate allies seems to point to how suited she might be to the domestic bliss of the Tesman household, while Hedda's 
past relationship with Eilert and razor-sharp wit seem to indicate that she could make a fine revolutionary in a parallel life. Class forms the key differentiation between Thea and Hedda's respective lots in life. To marry George and secure a place as a lady of a house, Thea would need the aristocratic upbringing and the shadowy promise of old-money wealth that come with being born General Gabler's daughter. Similarly, Hedda's station insulates her from ever having to make the decisions that lead Thea and Eilert together. Hedda cannot seek work, since employment would demean her status as a lady of society, and resultantly she never experiences the need to seek fulfillment through any means other than her marriage. When Hedda's marriage fails to amuse her, she is left with nothing to occupy her time, and she chooses to languish. Conversely, Thea has always had to take the initiative in her own survival, and in the midst of her sour marriage she finds meaning and purpose in her work with Eilert, which in turn provides a way out of her circumstances. For all her guilelessness that makes her susceptible to Hedda's vicious charisma, Thea is adaptable to her surroundings. While Hedda wilts under the pressure of her environment, Thea continually finds ways to recreate, or at times completely abandon, the parts of her environment that do not suit her. As different as these two women are, they do manage to find common ground within their domestic circumstances. They are both locked into unhappy marriages of convenience, and both are accidental mothers to children they do not claim. At the end of the day, both are grappling with their identity and place in a world that does not easily afford either of them opportunities for self-exploration.

In this final similarity we find the key to the most important distinguishing feature between the two characters: a sense of motion. Where Hedda stands still within the confines of her aristocratic life, Thea drives forward. She comes and goes from the Tesman house at will and is the only female character in the play who is not in some way a member of the household. She 
enters non-domestic spaces during her time offstage, and she comes and goes from the house without an escort. She is used to navigating the gray areas of social expectation from her youth in the middle class and her time working as a governess turned housemaid, then servant turned wife, in Magistrate Elvsted's household. Ibsen even goes so far as to have her wearing travel clothes for her first entrance and then later asks that she redon those same clothes for her final scene. In doing so, he sends a clear message: regardless of her delicacy, Thea is unafraid of uprooting herself in pursuit of her aims, and she is more than willing to move onward if the situation requires.

Thea also functions as a semi-covert catalyst for the main events of the play. On a surface level, she brings Eilert, and by extension their manuscript, into the household that brings about his and its tragic end. Her influence extends much deeper than this initial introduction, however. She is the woman behind that very manuscript, the scribe whose handwriting populates the pages of his book. When Hedda burns the manuscript, she claims to be burning Thea's child—her words. The parallel of child and manuscript is fairly obvious in some ways, as the book presents the union between his creative genius and Thea's organizational prowess. Less overtly, it signals a sense of equality in their partnership. Thea is not merely a scribe: she is acknowledged by Eilert as a coathor, a co-parent whose talent for nurturing Eilert's talent and keeping him on task and addiction free were as essential to the book's formation as any ability she had as Eilert's assistant. Their work together forms a kind of familial unit united by a passion and a shared responsibility that Hedda is incapable of realizing within her own life. In burning the book, Hedda attempts to dissolve this union. Even so, Thea and Eilert are not so easily separated. At the beginning of the play her persistence and bravery drive her to Christiania, both in support of Eilert and in hopes of reassembling her chosen "family." In the end, as she holds the scraps of their work together and faces defeat, she opts to persist. This delicate woman who is so easily dismissed even by the man 
who knows her best as "too silly" continually finds ways to rally in the face of her circumstances. Her significance lies in her strength in the face of difficulty, a feature which lies buried deep within the layers of the text, awaiting discovery. 


\section{CHAPTER THREE: First Meetings}

From this point forward, we enter an examination of the production process from the early stages of casting through the performance experience. Before we ever put a scene on its feet in staging rehearsals, the cast and creative team assembled to discuss the production team's vision for the play and to share renderings of the designs that would create the physical and atmospheric framework for the world of the play. These early meetings would also lay the groundwork for the cast's exploration of the play's text that would take place during the week of tablework that preceded staging rehearsals.

\section{The Director}

The show's director, Robynn Rodriguez, was brought in as a Guest Artist in Residency to WVU for eight weeks. A few days prior to auditions she stopped by during one of the graduate class periods to introduce herself and chat with us about her background. She described herself as being a San Francisco native who received her MFA in Acting from the American Conservatory Theatre alongside our program director, Professor Jerry McGonigle. She was a company member with the Oregon Shakespeare Festival for 22 seasons and appeared in 40 productions during her time there. She has also acted in productions in many theatres across the country, including the Guthrie Theatre, the Public Theatre, the Kennedy Center for the Performing Arts, and the Shakespeare Theatre Company. Her professional directing debut came in 2013 with a production of King John at the Utah Shakespeare Festival, and she described her directing resume as consisting largely of classical works.

In addition to possibly working with Robynn in Hedda Gabler, the graduate students would take an eight-week acting class on the works of George Bernard Shaw from her. In preparation for rehearsals, she told us to read Shaw's critique The Quintessence of Ibsenism when we had the 
chance. Although I fully intended to look over the essay, I quickly realized that the meager time between our introduction and the beginning of rehearsals didn't give me much leeway to read the text. I settled for a quick google search and surmised that the essay presents an analysis of Ibsenian characters and themes in Ibsen's major works. Having previously read a few of Shaw's editorial works before I also gathered that the essay would be lengthy and at times arduously verbose, so I opted to set The Quintessence of Ibsenism aside for future reading and then proceeded to completely forget about it once rehearsals consumed my time.

\section{The Casting Process}

The casting process took place over the course of a week, with a general audition followed by two nights of callbacks. Since all the acting graduate students were in our fourth semester of the program, by this point we were quite familiar with the faculty, and they with us. Robynn, however, entered the process as a guest artist who had never previously seen any of our work. Thus, the audition and callback process was much more reflective of the type of setting one might encounter when auditioning for an unfamiliar theatre company, where both actor and director would meet for the first time and attempt to get to know one another while navigating the casting process. We could not rely on the assumption that Robynn knew what we could do, but simultaneously we were freed slightly from the need to subvert presuppositions about our casting range that other faculty might have carried into the room. I relished the chance to present my work to a set of new eyes, although simultaneously I felt an increased pressure to showcase the entirety of my artistic range. As auditions and callbacks progressed, I found this pressure to be a hindrance that generated unhelpful anxieties (Am I enough? Did I do too much? Too little? Will my audition be enough to "win" a thesis-worthy role?), and I had to remind myself periodically that, as with 
any audition, casting would be affected by many factors beyond my control, and that all I could do was present my best work in that moment.

During the callbacks we were presented with sides and assigned scene partners to read with. We were then called into the room to read and walk through the scenes in front of Robynn, who would give us adjustments or discuss elements of the scene or characters with us. I was called into the room to read for both Hedda and Thea. While I enjoyed reading for Hedda, I struggled to find kinship with her character from the outset. Reading for her felt a bit like trying on an outlandish costume piece: fun to wear and twirl around in, but not necessarily something that I'd like to wear out in the world. I found myself drawn instead to Thea, whose speech patterns felt immediately familiar. Hedda's lines were cloaked in subtext; the motivations behind her words were constantly up for debate in a way that felt exhilarating to unpack, but her rapid shifts from warmth to coldness felt alienating to me. Thea, on the other hand, rarely concealed her true intentions for long, and I felt compelled by her openness and the warmth she exuded. At one point when I was supposed to read for Hedda I entered the audition room just as Robynn was concluding a conversation with another student about Thea's character, and I overheard Robynn describing Thea as "the bravest woman in all Norway." This observation felt revelatory to me, as I had already noted from reading various translations of the play in the weeks prior to auditions that Thea was often called upon by stage directions to behave with a sense of emotional fragility. I carried these words with me as I continued callbacks and challenged myself to find a sense of strength within Thea's outward delicacy.

Days later the cast list was posted, and I found that I had been cast as Thea. A few days before rehearsals began the cast was issued the script that we would be using: Jerry Turner's translation as performed at the Oregon Shakespeare Festival. In the leadup to rehearsals I read the 
script a few times and made a few preliminary notes and jotted down questions and observations to discuss in the first reading.

\section{The Director's Vision}

On the first day of tablework the entire creative team assembled for design and dramaturgy presentations. Robynn kicked off the evening by outlining her vision of the play and drawing the cast's attention to some key historical information on the time period. She contextualized the play as being set in the mid- $19^{\text {th }}$ century and stated that the American Civil War and the push for women's rights in both the U.S. and Norway were concurrent to the events of the play. By 1854, she said, Norwegian women were granted the right to inherit property like sons, and in 1863 male guardianship was abolished in Norway. She also commented that this period marked the entrance of scientific theory into daily and civic life. She then transitioned towards speaking to Hedda's experiences within the play and described her as a woman "caught between the aristocracy and the 'brave new world' of the $20^{\text {th }}$ century... she is incapable of creating a meaningful life from the world she inhabits."

Next, Robynn directed the cast's focus towards the language of the play. She emphasized the necessity of using the words on the page and stressed that nothing was casual or to be thrown away. "Because the language is so spare," she said, "we must use it." Throughout our five days of tablework she would return to this point again and again. She reminded us often to pay attention to operative words, to maintain an upwards inflection on questions, to "lift" the end of lines, and to invest in the discovery of any new information provided by other characters. She insisted that we observe punctuation, including dashes, ellipses, and question marks, and allowed the punctuation marks in the text to inform our reading of the lines. She also cautioned us against adding sounds or ejectives that were not written into our lines, observing that the temptation to 
sprinkle in an "ah" or a "hm" would dissipate the tension in the dialogue. Instead, we were to breathe through the line and act "on the text" rather than holding our breath and sighing it out between sentences. I found that Robynn's attention to linguistic detail echoed her experience with classical texts, as many of her directions on text interpretation focused on attention to the poetic structure of the lines. Though she never explicitly described the text as poetic she often referred to it as "heightened," in that the language of the characters was markedly more formal and pointed than contemporary colloquial speech. Throughout the tablework and rehearsal process the cast would receive myriad reminders and notes about line delivery that centered on these core principles. Robynn also highlighted that our cast had the benefit of using a script that had been recently translated by an American dramatist, as opposed to other translations which were primarily drafted by and for British audiences or created for the sole purpose of literary study. ${ }^{2}$ Thus, we could enjoy the gift of navigating a script whose grammatical style and word choice more closely reflected contemporary American English. While Turner's script would help ease a sense of imposed formality, Robynn again cautioned to avoid leaning too closely to informal speech that might undercut the social realities of our characters.

\section{The World of the Production}

To allow the entire creative team to build a cohesive vision of the world of our production, the designers, dramaturg, and vocal coach presented their work to the cast during the first day of tablework. As an ensemble we viewed the scenic models and costume renderings and listened to sound samples of music that would later be incorporated into transitions and pre- and post-show underscoring. The concept of dissonance surfaced in nearly all the designers' work. Professor Alan

\footnotetext{
${ }^{2}$ The fact that our production had access to this script was a rare gift indeed, as this translation was unpublished and was available to us through Robynn's associations with the Oregon Shakespeare Festival.
} 
McEwan's sound design relied on delicate piano pieces by Handel and Erik Satie, which were chosen to specifically create opposition to, as Robynn put it, the "turgid emotional life of the play." Similarly, MFA Scenic Design student Abbie Wagner's set design incorporated drab grey tones for the majority of the Tesman household's living room, with the exception of the portrait of General Gabler, which would be brightly colored and lit slightly brighter than its surroundings. Since Abbie chose to position the set on an angle to the audience seating, the inner corner of the living room where the portrait would be hung would function as the center point of the entire set, and the audience's eye would be drawn inward towards it unconsciously. I noted that though the set featured a back room where the piano would move after the first scene, Thea's interaction with the set would likely focus on the downstage half, which held the furnace, a chaise, a settee, and an armchair with a desk and chairs in the centerstage-left area. I also observed the height of the set, as the design incorporated large French windows and imposingly tall walls made all the more noticeable by all the paintings and portraits being hung from long, thin chains that extended towards the ceiling. MFA Lighting Design student Colleen Doherty also talked us briefly through her design choices and provided a short slideshow of images that invoked her lighting design, which primarily would consist of creating the impression of time of day or night, with occasional specials to draw the audience's focus towards central action while other characters populated the background of scenes. Next, MFA Costuming student Desi Childers displayed her costume renderings for each character's various costuming looks. For Thea, she planned to dress her in a blue-gray skirt with a matching traveling jacket and hat for the first scene when Thea has just arrived in Christiania. She had sketched a reddish-pumpkin gown with a golden speckled overlay and a faux-wrap detail to the bodice. She also informed me that Thea's first and final look were the same since the script indicates that Thea redons her traveling clothes at the end of the play. 
Professor Mary McClung presented last and briefly discussed her makeup design, which would consist of natural corrective stage makeup for all and wigs or hairpieces for the women. I noted that she intended to put Thea in a blonde wig, per the script's description of Thea.

Next came Dr. Jay Malarcher's dramaturgy presentation. I had been looking forward to his presentation the most, as I had hoped he would provide greater detail about day-to-day life as well as social and historical context for each of our characters. Unfortunately, his presentation mostly consisted of overarching commentary on dramatic structure and theory, which certainly might have been helpful to Robynn in guiding her view of the play's dramatic importance and function but was significantly less beneficial to a room of actors whose primary concern would be the microcosm of their characters' lives and experiences. He also opted not to provide a dramaturgical packet or any image references, so I made sure to take diligent notes on what he said so that I could process and recall the information as we continued tablework. He began by stating that Ibsen was writing in the era of the "well-made play," wherein dramatic works often delivered neatly packaged and digestible endings. He cited Nietzsche as an influence on Ibsen's work, particularly Nietzsche's theory of the balance between Apollonian and Dionysian impulses. He also briefly mentioned the ideals of existentialism, which broadly assert that each individual is on their own with no higher power to direct them and must consequently make their own choices. He stated that suicide represented the "ultimate choice" in the existentialist mode of thought, citing Albert Camus as a reference. He also mentioned Mary Wollstonecraft's 1792 publication $A$ Vindication of the Rights of Women as being contemporary to the time period while also remarking that the play takes place around the time of one of the French Revolutions. To finish, he described an anecdote on the Swedish novelist Victoria Benedictsson, a contemporary of August Strindberg who was purported to be a model for his character Miss Julie. Dr. Malarcher claimed that Benedictsson might also 
have been the inspiration for Hedda, and that she was rumored to have killed herself three days after seeing Ibsen's work Rosmersholm. By the end of the presentation I was struck by how little of the information felt helpful to informing the cast's perception of Norway during the time period, and I resolved to perform further research on my own to fill the gaps left in my understanding of how Thea might navigate quotidian life.

Professor Brianne Taylor, the production's voice coach, gave the final presentation of the evening. She offered us a handout with an IPA breakdown of Norwegian names and terms used in the script and modeled each of the words for us before asking the cast to repeat them back to her one by one. She also informed us that while we would not explicitly use accents in the production, we should consider a formal version of "So-Called General American" to be the vocal standard, which would require us to use a heightened oral posture and to enunciate our consonants clearly. She encouraged us to use our time in the table reads to "taste the text" as we explored the thoughts and intentions of our characters. 


\section{CHAPTER FOUR: Personal Preparation}

After establishing the directorial vision of the production, I began to consider how best to craft my own imaginings of Thea's place within the world of the play. While Robynn's insight would be instrumental to setting the tone for the production process as a whole, as an actor within this production I would be tasked with lifting the words of my character's dialogue from the page and breathing life into her text. Robynn's vision would offer a structure within which I could experiment and play in rehearsals, but I would ultimately be responsible for ensuring that the Thea seen by audiences would be a fully realized human being.

To do this, I decided to undertake some preparatory measures outside of the table reading process to better inform my vision of Thea's personal history and her context within the play's story. I began by outlining the play's events from her perspective and mining the text for any details of her backstory, including her personal relationships, social status, family history, and important life events. After establishing the through line of her narrative, I would be better positioned to make an informed decision on her point of view of the world around her and the people she interacts with throughout the play.

\section{Personal Dramaturgy}

In order to fully understand a character's context within their story, it is essential to break apart the script in search of any reference to their background and reassemble the pieces into a narrative that centers their experiences. This version of her narrative would not necessarily be fully represented in our staged version of Hedda Gabler, as Thea's personal story often became secondary during the points when she is off-stage, but clarifying her point of view, personal history, and relationships to the other characters is critical to bringing her character into the third dimension. 
With an Ibsen text the actor constantly has to balance what is said against what remains only implied, or even what is pointedly never mentioned. By first mining the text for overt mentions of Thea and then combing through for subtextual information, we can craft an initial rendering of her that can serve as a blueprint to build on in rehearsals. With all this in mind, I decided during the period of initial tablework to outline the major events of the play from Thea's perspective to clarify her point of view upon each entrance. The following expands upon the notes I made where I created act-by-act breakdowns of events that transpire when Thea is offstage and put them into the context of information she reveals or receives when interacting with other characters.

\section{Act I}

The first insights we receive on Thea come from comments made by Hedda and Tesman moments before she first appears onstage. We learn that her maiden name is Rysing, that she and Tesman once had a fling during their school days, and that Hedda also attended the same school and considered her to be a show-off with "irritating hair" (Ibsen and Turner 14). We also learn through a few off-handed comments from Tesman and Hedda that Thea has apparently moved north-"up there somewhere" in what Tesman describes as an apparently remote "neck of the woods" (15). The remainder of the clues to Thea's origins revealed in this first act of the play come from oblique statements Thea makes to Tesman and Hedda, and later once the women are left alone, to Hedda. Thea has stepchildren that she demurs in claiming as her own, Eilert Løvborg moved in with her and Mr. Elvsted, during which time she assisted him in writing his popular new book which has been published just weeks ago. Yet Eilert disappeared the week previous and returned to Christiania, a cause for concern given that he suffered from alcoholism in the past and only recently recovered under Thea's influence. When directly asked by Hedda about her stake in 
the matter of Eilert's return to the capital, however, Thea deflects, and Hedda is only able to find out Thea's wistful romantic yearning for Eilert once she nudges Tesman out of the room. We also find a great deal of personal information on Thea's self-image: Hedda used to bully her in school, Thea is apparently unaccustomed to affection from others, she reportedly never had a place that she called home, and when she first came to the Elvsted household as a governess she was put in charge of caring for the magistrate's invalid wife as well as the housekeeping. Her marriage, which took place five years prior, was one of convenience, and she and her husband share no affection, although it does not appear that Mr. Elvsted has been overtly unkind so much as emotionally negligent. Once Eilert joined the Elvsted household as a tutor for the children, Thea split her educational duties with him and over time became his secretary, then his writing partner. Gradually their friendship became more intimate, until Eilert relied on Thea's insight for his book and she began to glean the emotional contact from him that she was missing from her marriage. He then disappeared, and she secretly left in pursuit, fearing that he might return to his old ways of drinking and womanizing.

From this information I began to thread together the narrative of Thea's past. Thea is described on first entrance as being two or three years younger than Hedda, who is 29 , so we can surmise Thea is $26-27$ years old. She also states that she was a year behind Hedda in school, so either her birthday falls in such a way that she is on the younger side of her class or at some point Thea advanced more quickly through her studies than usual. She was married at age 21 or 22 , and she spent some amount of time as a governess with the family between leaving school and marrying Mr. Elvsted. There is also an interesting exchange between her and Hedda that provides clues to the degradation of her marriage:

HEDDA: So, finally, you became mistress of the house? 
MRS. ELVSTED: Yes, I did.

HEDDA: How long ago was that? I can't remember.

MRS. ELVSTED: When I got married, you mean?

HEDDA: Yes.

MRS. ELVSTED: About five years ago

HEDDA: Yes, I thought it must be about that.

MRS. ELVSTED: Five years ago. Oh Mrs. Tesman, if only you knew-. Especially for the last two or three.

Hedda redirects Thea from this thought before she has a chance to finish it, but we could surmise that it ends with her detailing how intolerable and lonely her marriage has become in recent years. Ibsen leaves the emotional origins of those last few lines up to the actor, however, which yields another possible reading. Perhaps Thea is actually beginning to hesitantly describe another kind of shift that night have rattled her marriage — her growing attraction of Eilert Løvborg. We know definitively that Eilert wrote his book at the Elvsted's over the last year, but perhaps he moved there before beginning his recently released book, and Thea got to know him as he tutored the Elvsted children. Another easily overlooked passage in the scene can similarly provide clues to the mysteries of Thea's late adolescence:

HEDDA: You can speak to me, surely. After all, we went to school together.

MRS. ELVSTED: Yes, but you were a year ahead of me. I used to be frightened of you in those days.

HEDDA: Frightened of me?

MRS. ELVSTED: Yes, terribly frightened. Whenever we met on the staircase you used to pull my hair. 
HEDDA: Really? Did I do that?

MRS ELVSTED: I was so silly in those days. And then, afterwards, - I mean we've drifted so much apart. Our backgrounds were so different, I mean.

The awkwardness of Thea's lines here clearly establishes that she and Hedda were not schoolgirl friends, as Hedda attempts to so smoothly assert. A closer look at Thea's final line, however, yields yet another passage where Thea begins a thought and then cuts herself off with a pregnant pause, as signified by the dash. What is the event that Thea begins to describe before redirecting to a discussion of their class differences? Here, I had to rely on some research outside of Ibsen's text. The Norwegian schools of Ibsen's day were typically integrated across social lines, so Thea attending a school populated by wealthier children like Hedda would not have been all that uncommon (Lauglo 269). Victorian social mores, however, indicate that women, and specifically well-to-do ladies, who sought gainful employment did so at the expense of their social standing. Despite some movements towards gender parity, a woman's status was determined by how decorative she managed to be within her own household, and accepting money blemished her ability to exist as a symbol of leisure (Peterson 10). Thea's social origins are murky, and although her history of deference to Hedda seems to signal that she views herself as subservient, we cannot know definitively what class she was born into with the information provided in the script. We can ascertain from her needing to take a job as a governess, however, that she was financially selfreliant by her middle to late teens. The need for Thea to seek gainful employment could have been an inevitability of her being born lower or middle class, or perhaps it was a byproduct of Thea's familial support system suddenly losing their income and forcing Thea to seek income for her own survival. Marrying the magistrate would have helped her to gain, or regain, a higher social standing, but her newfound status is muddied by her tenure as a governess. The children she has 
been tasked with rearing are not hers, the house she lives in is one she used to clean, and the family name she carries is a hand-me-down from the magistrate's first wife.

Based on the events in this first scene, I created the following pre-Act I timeline:

- Age 16: Thea and George Tesman share a brief romantic fling. Hedda bullies Thea.

- Age 17-22: Thea finishes school. Eventually finds work as governess and housekeeper with the Elvsteds. Cares for Mrs. Elvsted until she dies.

- Age 22: Marries Mr. Elvsted.

- Age 24: Meets Eilert Løvborg when he arrives to tutor the children.

- Age 25: Eilert begins work on his book, which has been recently published. Shortly after, he begins to work with her on its sequel, which currently exists in manuscript form.

- Age 26: A week before the start of the play Eilert leaves for Christiania. Thea takes a train to Christiania to visit the Tesmans and arrives the day before the play begins. She is turned away as the Tesmans are not due to return until the following morning. She returns a few hours before the start of the play to find that the Tesmans are still asleep, so she leaves flowers and a note stating that she will return in a few hours.

\section{Act II}

Only a few hours separate Act I and Act II, so my timeline covering the distance between Thea's exit and next entrance was fairly simple: the sole concrete event of Thea's day referenced between the two acts is when Eilert mentions running into her during the afternoon sometime. Just before she enters we hear Eilert and Hedda discuss whether Thea is aware of their previous attachment:

HEDDA: I'm sure you told her about us. 
LØVBORG: Not a word. She's too silly to understand that kind of thing.

HEDDA: Silly?

LØVBORG: She's silly about that kind of thing.

We can glean two important bits of information here: that Eilert has explicitly kept his affair with Hedda from Thea, and that he senses that she would not be happy if she did find out about it. The repetition of "silly about that kind of thing" deserves some attention as well. Has Eilert previously discussed his pre-teetotaling past with Thea and received a negative reaction? Does he perhaps have an inkling of her attraction to him, and is attempting to protect her from Hedda's ire? Or is he uncomfortable with the knowledge that Thea has romantic feelings for him and attempting to dismiss her as "silly" so that he does not have to untangle the complexities of their friendship?

I also noted a brief moment in Thea's dialogue that offers further clues to what lies between her and Eilert:

LØVBORG: We're the best of friends. Comrades. We trust each other implicitly. We can talk to each other without reservations.

HEDDA: No need to be oblique, then?

MRS. ELVSTED: Imagine, Hedda. I'm so happy. He says I inspire him.

HEDDA: Does he really, Thea?

LØVBORG: She has great courage, Mrs. Tesman.

This segment takes place at a point when Hedda and Eilert are needling each other about their own shared past while Thea unwittingly looks on. While Hedda and Eilert are speaking in veiled terms and pointedly referencing earlier parts of their conversation that took place prior to Thea's arrival, Thea's comment seems heartfelt. She truly believes Eilert when he tells her she is inspirational, although whether he is fully committed to that sentiment rests in the jurisdiction of the actor 
playing him. She adores this man and feels almost confounded by the idea that she could in some way serve as an inspiration to him.

The next section of the scene moves into dangerous territory for Eilert and Thea. Sensing that Thea might have more influence over Eilert than initially thought, Hedda teasingly prompts him to drink liquor and is unsuccessful, until she reveals that Thea visited the Tesmans seeking help on Eilert's behalf. This invasion provokes a rage in Eilert, and he begins to drink glass after glass, toasting Thea with each drink. After Hedda reins him in, he realizes the gravity of his actions and apologizes to Thea:

LØVBORG: That was silly of me, Thea. To take it like that, I mean. Don't be angry with me, dear friend. You'll see... You'll see along with the rest of them. I was a fallen man, but I have risen again. And it was you, my comrade, who helped me.

Thus, we can surmise that perhaps Thea's devotion to Eilert is reciprocated in some small way. We see him refer to her again as a comrade, but this time he affectionately addresses the term to her directly. With this speech, he confirms Thea's assertations from the first scene that she has acted as his partner, both in writing and in friendship.

\section{Act III}

Act III brings us to seven o'clock the following morning. Thea and Hedda presumably consumed the tea that Berte prepared for them at the end of the previous act, and they stayed awake until four o'clock waiting for the gentlemen to return from the party. While Hedda is sound asleep at the beginning of the scene Thea mentions sleeping only fitfully through the early hours of the morning, if at all.

Later, Thea leaves the stage to try to get more sleep in Hedda's room and reenters to find a disheveled and quite distraught Eilert in the living room. Thus begins the downfall of their 
connection — by the end of the scene Thea, under the misapprehension that Eilert has destroyed the manuscript that represents their joint life's work, will leave Eilert for good. In this segment we achieve confirmation of the depth of their bond:

MRS. ELVSTED: You can't just drive me away like that. I want to stay here—be with you when your book comes out.

HEDDA: The book, yes.

LØVBORG: Our book-Thea's and mine. It belongs to both of us.

While Thea is initially content to ascribe ownership of the manuscript's genius, Eilert is quick to correct her so that they share the credit. Later after Eilert tells Thea that he has shredded the book and dropped the remnants in the fjord, she responds:

MRS. ELVSTED: Eilert—What you've done with our book—I can't help it—I'll always feel to the end of my life-it's like killing a child.

LØVBORG: You're right. It's like killing a child.

MRS. ELVSTED: How could you do it? It was my child, too.

For Thea, this book has given her purpose, alleviated her loneliness and boredom in her husband's house, and saved her from a meaningless existence. She sees the pages and ink as the flesh and blood of her own family - notably, the only familial bond she readily claims in the script. For her, the partnership she has found with Eilert transcends a working relationship; in her eyes, they are parents and share a bond as sacred as any marriage. Eilert's destruction of the manuscript without her knowledge or consent negates that bond and erases not only the significance of the work they performed together, but also the significance she might have had to him. A weaker person would disintegrate at this revelation, but Thea instead opts to take her chances beyond the Tesman house-alone. She leaves unescorted, fully accepting the uncertainty of her future 


\section{Act IV}

Thea walks out into the morning, and she presumably goes back to the room she is renting in Christiania. On her way back she runs into Tesman and tells him that Eilert destroyed their manuscript. Since she reenters for this act in her travel clothes, she must have been in her rooms long enough to change clothes, pack, and retrieve Eilert's notes. She seeks him out at his rooms presumably to return them to him, but she is unable to find him, although she hears whispers that he was involved in some violent accident. Her fears are confirmed when Judge Brack enters and shares the news of Eilert's mortal injury from an apparent suicide attempt. The judge's story is called into question briefly when Thea recalls the time that she went to see Eilert:

MRS. ELVSTED: When did all this happen, Judge Brack?

BRACK: This afternoon. Between three and four.

TESMAN: But good heavens-where?

BRACK: Why, at his rooms, of course. Where else?

MRS. ELVSTED: No, that's impossible. I was there soon after six.

The judge quickly deflects that perhaps the incident took place elsewhere, and Thea accepts this as truth without further question. Later the audience discovers that the hole in the judge's story reveals the lie in his account_-Eilert shot himself, yes, but by accident during an altercation with Mademoiselle Diana, an old paramour from his drinking days. This revelation dos not enter Thea's awareness, however, and her belief in the veracity of his suicide drives her to attempt to resuscitate his manuscript:

MRS. ELVSTED: I kept the notes he dictated it from. They're here, in fact.

HEDDA: Ah!

TESMAN: You kept them, Mrs. Elvsted? I mean, you have them? 
MRS. ELVSTED: Yes. I brought them with me when I left home. They're in a terrible muddle. All mixed up.

TESMAN: Just imagine if we two could sort them out? We could work together, perhaps. MRS. ELVSTED: We could try, anyway.

The act of reviving the manuscript is a memorial to Eilert that also heralds the reignition of the school days era friendship between Thea and Tesman. This becomes concrete when Tesman says: TESMAN: You and I will have to combine our brains, Mrs. Elvsted. We can't undo what's been done, you know? We must approach this thing calmly.

Hedda begins to recognize throughout the scene that in destroying Eilert's manuscript she has in some sense destroyed her influence on the people around her. This is notably the one scene where Thea and Hedda share a space but direct little dialogue to each other, and even Hedda's attempt to ingratiate and perhaps manipulate Thea backfires:

HEDDA: Does it feel strange, Thea, to work with Tesman just the way you used to work with Eilert Løvborg?

MRS. ELVSTED: Wouldn't it be wonderful if I could inspire your husband like I did him? Thea fails to recognize the insult in her words, that she has twice now acted as an inspirational force for the men in Hedda's life. For what little is left of the play's action, Thea diligently works with Tesman on reassembling the manuscript. They quit their work only when they are interrupted by the fatal gunshot that signals the end of Hedda, and thus the conclusion of the play.

\section{Key Phrases}

After clarifying the events of the play from Thea's perspective, I decided to make a list of phrases from her dialogue that signify her point of view towards herself and others. This exercise is a replication of a practice I learned in Professor Jerry McGonigle's Meisner class. He broadly 
defined point of view as the meaning a character assigns to people and events that happen onstage. To further our development of a character's point of view, he would direct us to read through the entire play from which the character originates and select "key phrases," which are lines of dialogue spoken by an actor's assigned character that reveal their truthful perspective on a global scale. While this list of key phrases can initially be quite expansive, eventually the actor must whittle them down to the top three or so most important lines, with the aim of finding one phrase that most succinctly represents the character's inner truth.

After a close reading of the script, I decided upon the following five phrases as my starting point:

- I only know I must be wherever Eilert Løvborg is, if I am to go on living at all (24).

- I want to share the joy with you (77).

- It's like killing a child (78).

- I came to have a kind of power, almost, over him (24).

- I didn’t see what else I could do (23).

I noticed right away that three of the phrases came from Thea's conversation with Hedda in the first act, and the other two from her conversation with Eilert during the scene when he reveals that he has destroyed the manuscript. For Thea, these are the moments in the play when she is speaking the most freely and honestly without being encumbered by the fear of upholding social propriety. While all five of these phrases are evocative of important elements to Thea's views, I felt drawn to one phrase in particular: "I came to have a kind of power, almost, over him." In this line Thea is describing her increasing influence over Eilert during the course of their friendship. She influenced him to quit drinking and encouraged him through the writing of his two most prolific literary works, and in turn he invited her into his work to be an equal partner in his writing. Thea's 
words here feel hallowed yet are tinged with self-effacement in her need to qualify the word "power" with "almost," as if perhaps she is questioning her word choice or the idea that she of all people could hold sway over a mind as brilliant as Eilert's. This line represents the beginning of their joint work and her attraction to Eilert, and it also signals that, for all her demurring and hesitancy, Thea unwittingly possesses the ability to mold the world in her hands. As Hedda astutely remarks later in the play, "That pretty little thing has been shaping a human destiny" (78). Thea cannot fully believe the thought and thus only hints around it here in an incredibly confidential way, but dismissing her full abilities is in some sense part of what makes Thea, Thea. She drives much of the play in terms of plot and action, yet in a moment of truthfully exploring her own potential she can only give partial voice to the idea.

After making the list of key phrases I filed it away in my rehearsal journal so that I could refer back to it once blocking rehearsals were underway.

\section{Inspirational Images}

An audience will only see the portion of the play's physical world that is represented by the set, but an actor must have a cohesive vision of the world of the play beyond the stage's edge. What scenery is the character accustomed to seeing? Where did they just arrive from prior to their entrance, and where will they go upon exiting the stage? To answer these questions, I decided to seek out images that might help illustrate Thea's view of the world outside the Tesman house. Since during this time photography was still a new technology, I noticed that most photographs I viewed were formal portraits or served the purpose of documenting rather than artistically rendering their subjects. I wanted the images I found to provoke my own imagination of Thea's world, so I looked instead to painters of the era and expanded my search from there. Overall, it was less important to me for the images I found to be strictly historically accurate; instead, I wanted 
them to evoke color, light, texture, and feeling so that I could tinge my imaginings of Thea's life with a sense of subjectivity that might reflect her own personality and experiences.

\begin{abstract}
I started by
looking for paintings by

Norwegian women who

would have been active

during the span of

Ibsen's writing career,

and I was immediately

drawn to Harriet

Backer's 1890 painting

By Lamplight (Figure 1).
\end{abstract}

The image seemed like

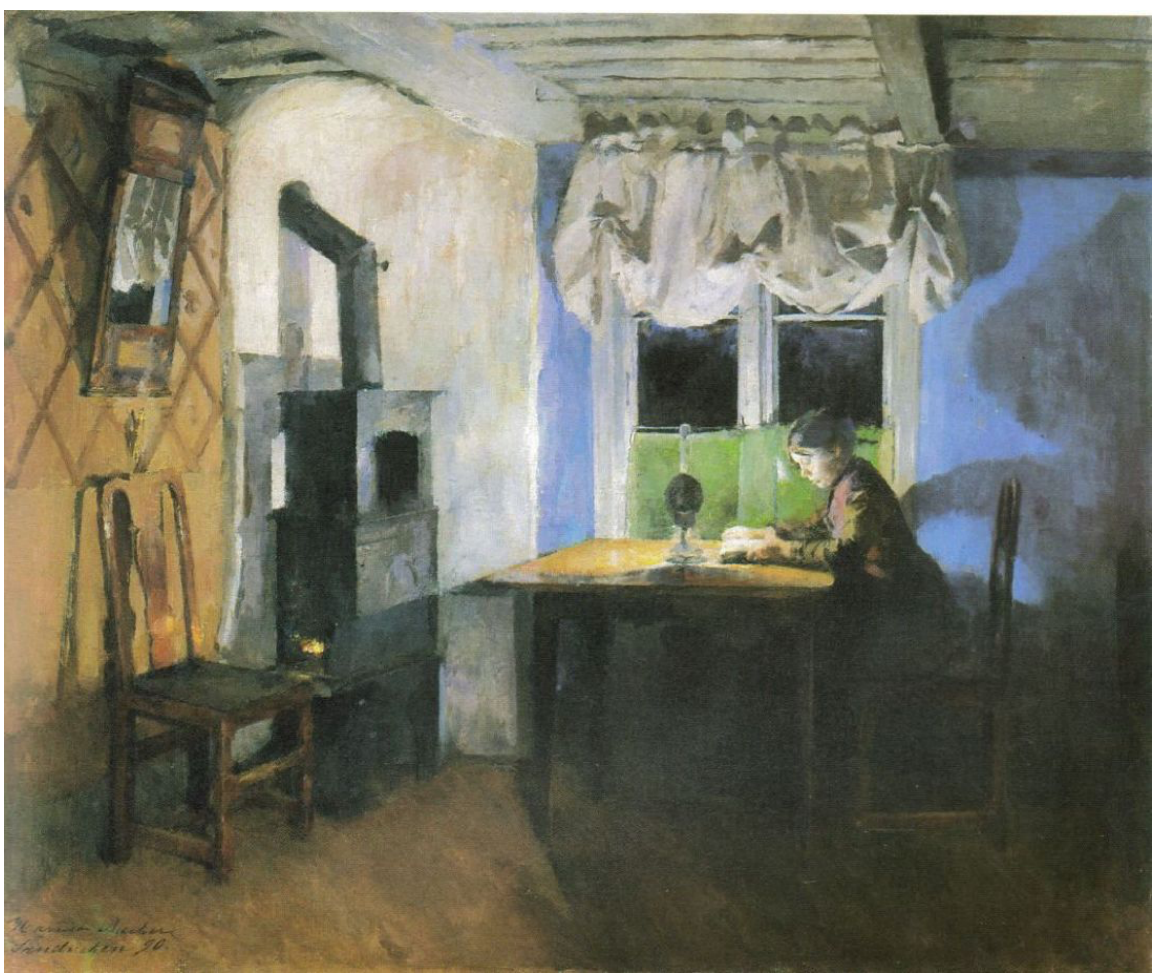

Fig. 1: Backer, Harriet. By Lamplight. Oil on canvas, 1890. The Eclectic Light Company.

something straight out of Thea's life in the Elvsted household - a woman working alone by lamplight in a rather austere nighttime setting. The softness of the valence over the window seems at odds with the strong shadows thrown behind the seated figure, as do the stark delineations between the light indoors and the darkness showing through the window. Additionally, I noted the patchwork of umber, white, and blue walls, which for me felt like a nod to Thea's relationship to her household, where in a sense, she has been patched into the lives of the Elvsteds, first as a governess turned housekeeper, and later as a wife of convenience to the magistrate. The woman reading at the table seems at peace with her surroundings, but simultaneously she feels isolated. She is alone in this world, with only her book for company. In viewing the image I could begin to see the outline of Thea's life as a governess, how she might have begun to feel that she was fading 
into the furniture. The book in her hands is the stimulant that keeps her grounded and brings her figure back into tangibility.

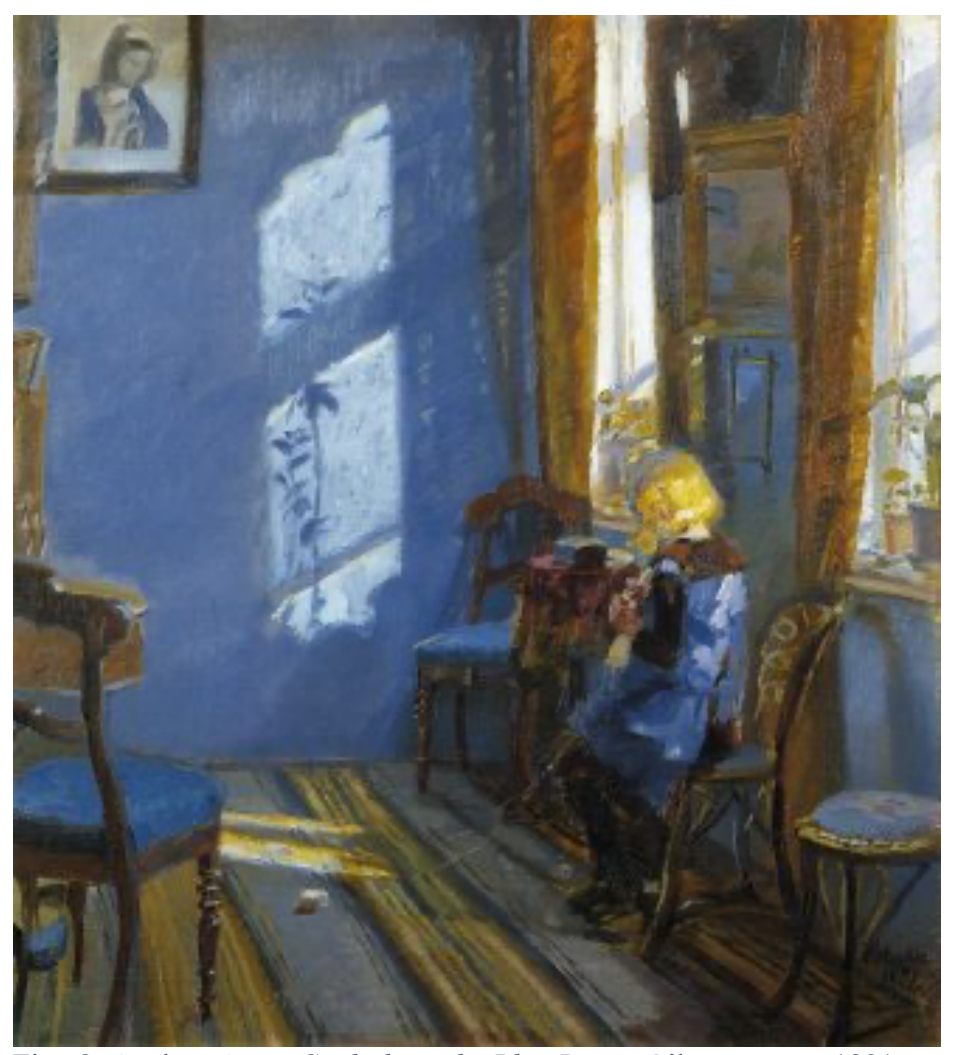

Fig. 2: Ancher, Anna. Sunlight in the Blue Room. Oil on canvas, 1891. Skagens Kunstmuseer.
I then stumbled across another portrait of a lone figure surrounded by blue: Danish painter Anna Ancher's Sunlight in the Blue Room (Figure 2), painted in 1891. This image evoked a softer narrative for me, as if it reflected a moment of solitude in Thea's childhood. Again the figure is absorbed in a small task, and again she matches her own background so well that she practically fades into it, except for her brilliantly blonde hair.

Looking at the painting, I began to envision the version of Thea who was so annoying to Hedda as a schoolgirl, a demure and methodical child who by all rights should be unnoticeable, save for a natural luminosity that settles around her like a corona. The blue and ochre colorway reminded me of the blue of Thea's traveling clothes. I began to feel that these colors could be familiar and comforting to Thea, perhaps reminiscent of some object or place from her unmentioned childhood. My final image in the blue-and-ochre theme was Théodore Géricault's 1818 Portrait d'Elise et Alfred Dedreux (Figure 3), which I discovered as I looked for images that might represent the children Thea cares for as a governess. I found this portrait to be slightly sinister; the 
children's poses feel forced and unnatural, and their expressions seem to imply a sense of criticism towards who or whatever they are looking at. Here, the repetition of the blues and browns seems to underscore the eeriness of the children — these hues that offer comfort and life in the previous two images are deadened and sickly here, and they are sharply divided between the land and skyscape by the darkness of the mountains. This image strongly invoked an idea of what the Elvsted children might

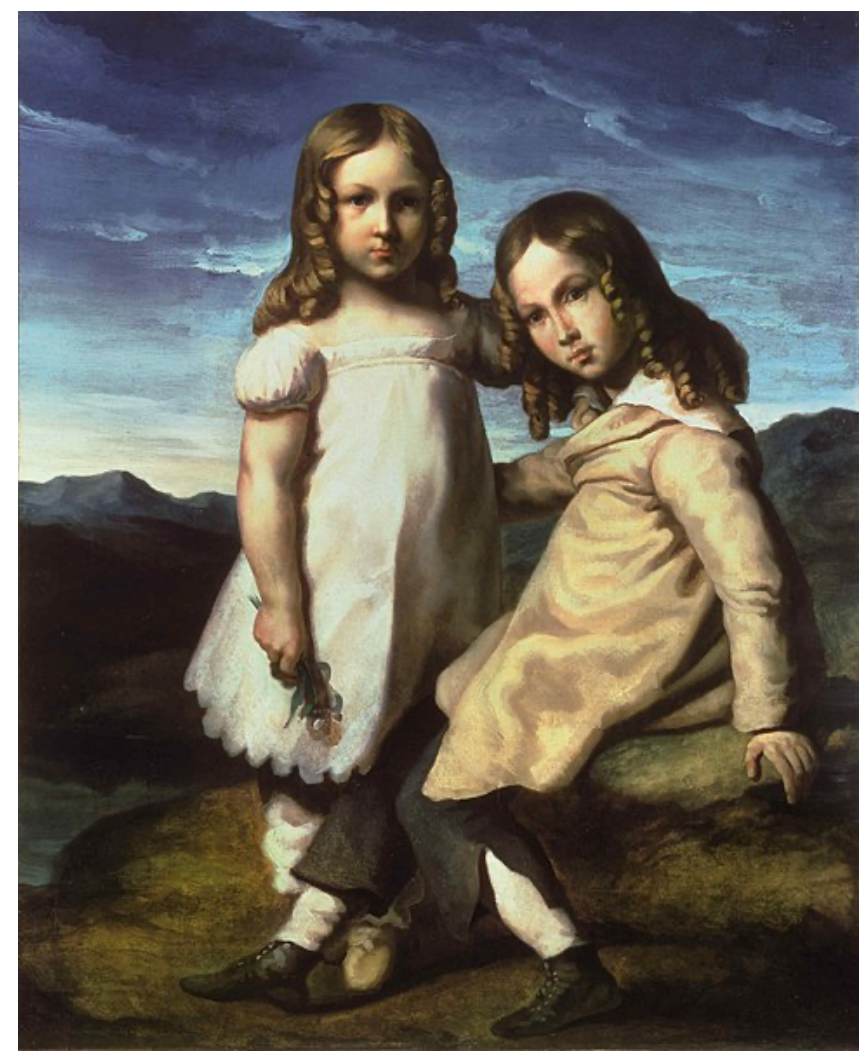

Fig. 3: Gericault, Theordore. Portrait d'Alfred et Elisabeth Dedreux. Oil on canvas, 1818. Christie's.

have looked like to Thea. While they are not necessarily hostile, they lack warmth or compassion. Their aloofness grants them a worldliness that belies their childlike proportions and clothing.

After finding the image of the children I wanted to shift towards images that might speak to Thea's relationships to Eilert and the manuscript they have created together. Here the images became significantly less literal than the paintings I found earlier. I drew upon a number of abstract images, sketches, photographs, and sculptural works to inform my view of how her friendship with Eilert grew in complexity during their time in the Elvsted household. I first found a Rothko painting, Untitled, Black on Gray (Figure 4), after fumbling around in Google images with various search terms. On first view, the austerity of the image's lines felt reminiscent of Thea's isolation, and the longer I looked at it the more I noticed the subtle texture of the gray field against the void of darkness above. The infinite depth of the top half of the painting feels daunting yet inviting, like 


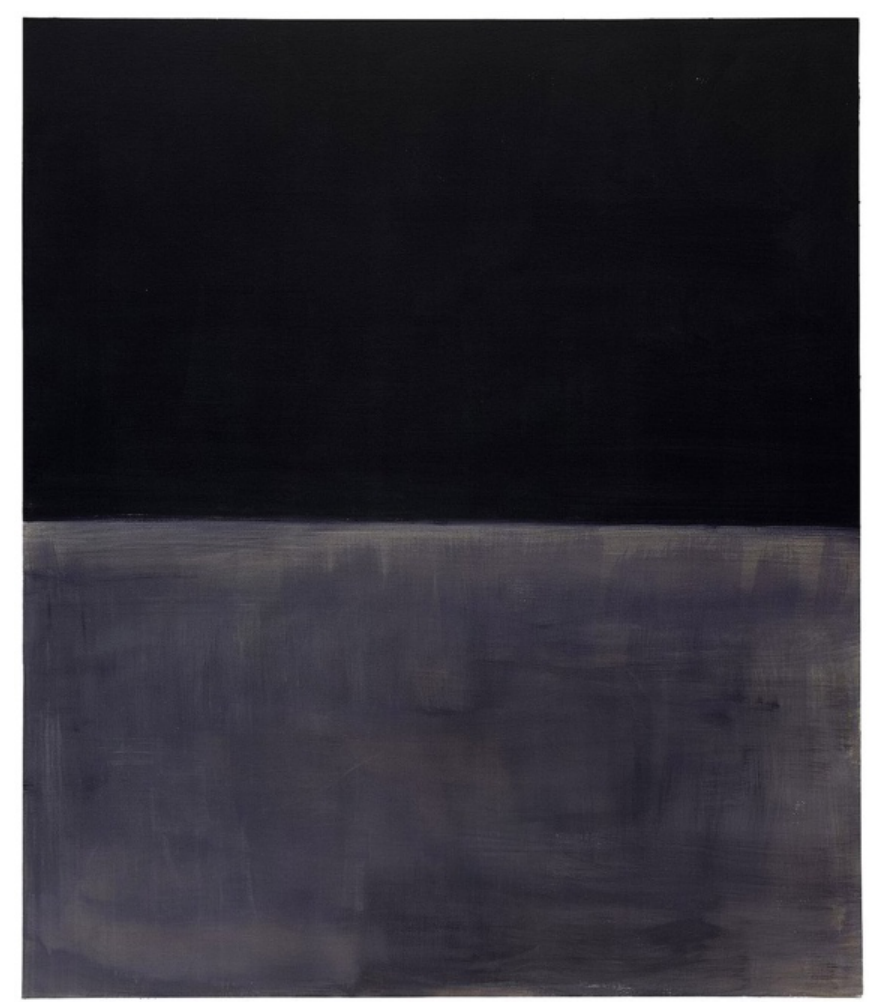

Fig. 4: Rothko, Mark. Untitled (Black on Gray). Acrylic on Canvas, 1969-1970. Guggenheim. a great expanse of unknown territory resting just beyond a dim horizon. I began to see the shades of lightness just at the meeting place between the two halves of the painting, which for brought to mind my key phrase from the script, "I came to have a kind of power, almost, over him." I then cast around for an image (Figure 5) that invoked that sense of electric power, and after a period where I tried to be clever with my search terms and find some existential portrayal of the abstraction of power, I

stumbled across a photo of literal electricity. The image is a humbly untitled picture in the public domain, yet the shimmer of the glass, the tangled web of filaments, and the seemingly random arrangement of the bulbs perfectly captures the juxtaposition between Thea's uncertainty and the magnetic pull she feels toward Eilert. In the times that we read the script during table reads I could sense the beginnings of a connection between the two characters as strong as an electrical current, so it felt at once

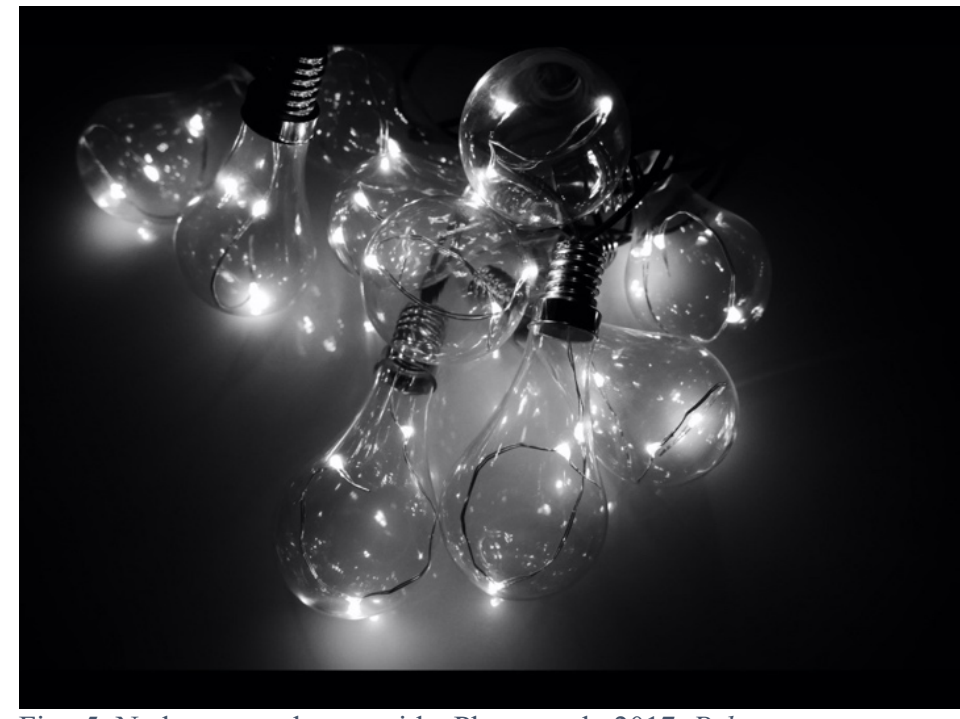

Fig. 5: No known author, no title. Photograph, 2017. Pxhere.com. 
perfectly right and incredibly on the nose that my curated mental image suit that nuance of their relationship.

In a move that felt both poetic and absurdly obvious, I chose a picture of a book (Figure 6) to represent the manuscript. Specifically, the pages in the image are pulled from maps and arranged in a swirling, organic pattern that reminded me of a biology model of the various parts of cellular structure. The ribbons of pages that weave

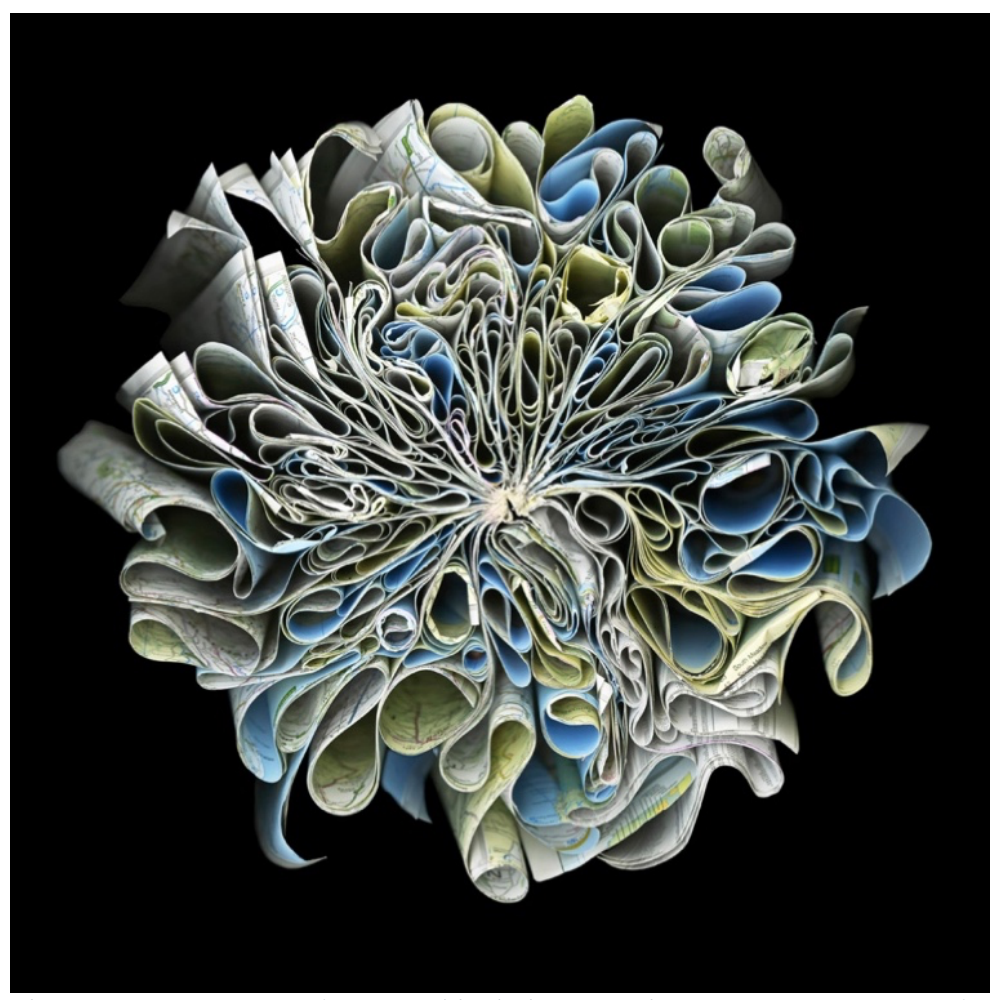

Fig. 6: Barer, Cara. Explorer. Archival pigment print on rag paper, 2011. The Week.

together fan from a central point, yet it feels nearly impossible to determine where pages truly begin and end; all the leaves of paper intertwine into a being so complex that it practically breathes. I was amused to see more green and blue peeping between the pages-very on brand for my growing collage of Thea's psyche. The sense of movement and life that emanated from the sculpture corresponds with Thea's personification of her work with the manuscript and its transcendence from ink and paper to a living creature with as much potential to exist and thrive as any human child.

For my final two images, I sought out images of the Norwegian countryside so I could establish the scenery that Thea might be accustomed to seeing in her time outside of Christiania. I 
first found a photo of several men standing alongside horse-drawn buggies in front of the Mundal Hotel (Figure 7). The intricacy of the turreted hotel building, though beautiful, is nearly absurd against its backdrop of a craggy,

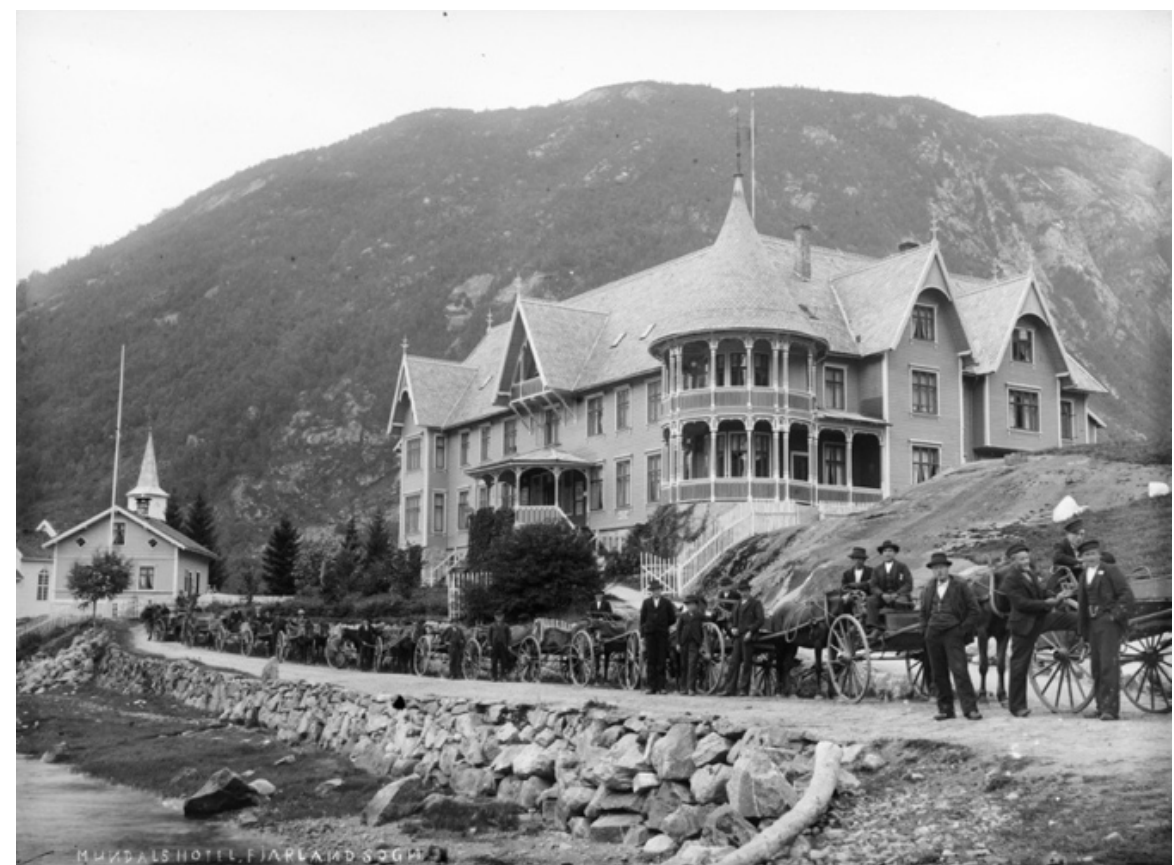

Fig. 7: No known author. Mundal Hotel. Photograph, ca. 1890-1910. The Nordic Page.

forested mountain. I recalled from my research on Norway's rail lines that many of the lines had been constructed in the latter half of the nineteenth century, so it made sense that such an ornate building would have been freshly erected in a remote place. While looking at the photo I wondered if perhaps the Elvsted's house might not evoke similar feelings of misplaced grandeur that clashed with the surrounding countryside.

My final image turned out to be my favorite, a photograph of an autumnal Norwegian landscape by Jan Erik Waider (Figure 8). Initially I failed to notice the house nestled between the trees amidst all the variations in color, light, and texture in the photo; I was instead drawn to the drama conveyed through the natural world, with the fog seeping between the layers of trees slashed with vibrant golds and yellows, and greens so dark they looked black. Once I finally noticed the little house, I was overcome with the sensation that it was being slowly overtaken by the surrounding foliage. The trees by comparison feel giant and ancient, like stoic sentinels to the house's suffocation. I felt emotional when looking at the image; it felt like such a visceral 
representation of Thea's experience of being slowly buried alive in the wilderness. The tidy little house peeking between the trees would become one of the most poignant references for my vision of Thea's inner world.

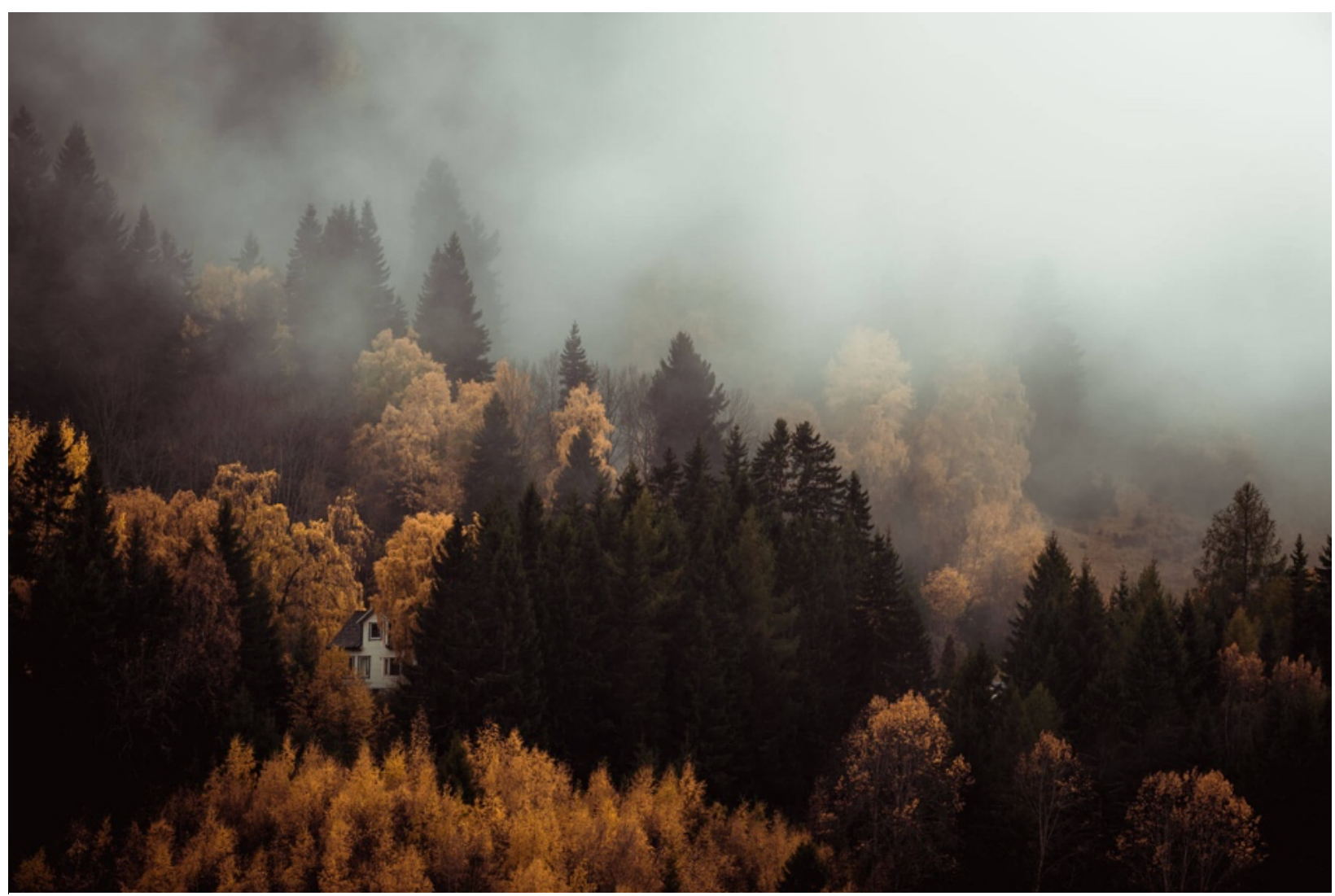

Fig. 8: Waider, Erik Jan. "Fleeting Moments of Autumn: Fjord Norway." Photograph, no date. Northlandscapes. 


\section{CHAPTER FIVE: Methodology of Character Development}

At this point the time had come for the cast to enter the rehearsal space and begin to put our visions and ideas of our characters on their feet. As we progressed through rehearsals, I wanted to give myself a framework in which I could begin to marry my imaginative explorations of Thea's experiences with the practical work of building her into a three-dimensional being who could move and breathe in space. This framework would help lend a sense of structure to the process of character creation, so that I would be able to continuously build on character discoveries made both in and outside of the rehearsal room as time went on. To do this, I turned to Tremorwork®, an element of Fitzmaurice Voicework ${ }^{\circledR}$ that I studied under Professor Brianne Taylor in the three semesters leading up to rehearsals for Hedda Gabler.

While a discussion of the applications and nuances of this work could rightly form its own dissertation, here I will specifically focus on the elements of the technique that I used in this specific rehearsal process. Catherine Fitzmaurice has yet to publish a set primer or manual on her work, and many elements of Fitzmaurice Voicework ${ }^{\circledR}$ have continued to evolve since my writing of this chapter. The following will create context for common terms, images, and exercises used by Fitzmaurice practitioners at the time of our production.

\section{Fitzmaurice Voicework®: The Basic Mechanics}

Fitzmaurice Voicework ${ }^{\circledR}$ is a vocal pedagogy developed by Catherine Fitzmaurice, an actor and vocal practitioner whose artistic career began at the age of three ("Breathing is Meaning" 3). She began developing her titular work in the mid-1960s while working at the Central School of Speech and Drama in London. Much of her work's early influences derive from the writings of Wilhelm Reich and the teachings of Alexander Lowen's Bioenergetics and John Pierrakos' Core Energetics. As she continued to develop her techniques through the 1970s she began to incorporate 
yoga and Reiki methods into her voicework (3). At its heart, Fitzmaurice Voicework ${ }^{\circledR}$ centers on freeing the breath from unnecessary tensions to enable the actor to produce sound that is uninhibited, vibrant, and spontaneous. To do this, Fitzmaurice created a series of pragmatic exercises, together known as Tremorwork ${ }^{\circledR}$, that encourage the actor to fully relax their torso, and thus the muscles associated with breathing, while engaging various extremities of the body in a reflexive, tremoring reaction. The tremors (which are distinct from spasms or voluntary shaking ${ }^{3}$ ) pass through the body and begin to unknit unconstructive tensions within the musculature ("Breathing Matters" 3). As the vibrations of these tremors travel through the body, they ultimately impact the actor's breath, shaking loose habitual breathing patterns and prompting the actor to breathe more spontaneously and efficiently (4). This pursuit of the free, spontaneous breath through these exercises is commonly referred to as Destructuring, in that the actor seeks to peel away habitual structures surrounding their movement, carriage, and breath. The action of inducing an involuntary tremor into the body invites a sense of chaos into the actor's physical, mental, and emotional state that is intended to breed freedom and discovery in the breathing impulse. Once an actor has experienced this Destructured state, they can begin the process of Restructuring, where they start to reconcile their (or their character's) mental and emotional needs in any given moment with the body's need for oxygen. In Restructuring an actor invests in efficient inhalation and exhalation supported by the deepest layer of the abdominal muscles, the transversus abdominus (7). This muscle is the largest of the abdominals and wraps around the entire lower torso like a massive wresting belt with connections to the pelvis, lower ribcage, and lumbar spine. Many performers are familiar with the insistent cry of myriad vocal coaches to "breathe from the

\footnotetext{
${ }^{3}$ See Fitzmaurice Voicework: Constructing the Holistic Actor pages 51-52 or a detailed description on the differences between tremoring and other reflexive physical actions
} 
diaphragm," which asks the performer to discern whether they are engaging a muscle which is highly internal and which does not contain sensory nerves (Armstrong). By instead engaging the transversus the actor is able to focus the effort of their breathing on a visibly obvious, voluntary muscle that naturally lifts the ribcage as it moves rather than compressing the ribcage as the other muscles of the torso might do when overly engaged ("Breathing Matters" 7).

Our graduate class was introduced to the postures ${ }^{4}$ of Destructuring under the instruction of Professor Taylor in the following sequence: Butterfly, Clockface, the Wave, Dying Cockroach, Open Book, Hammock, Mermaid, Rocking Horse, the Blarney Stone, Healthy Cow, Blue Bottomed Baboon, Fold Over, Standing, and Bowback. As we became familiar with the postures Professor Taylor encouraged us to explore variations in order and duration with each posture of the sequence both to deepen our exploration of the Destructuring and to allow room for adjustments for our physical and emotional needs on any given day. It should also be noted that though the language of Fitzmaurice at the time of this rehearsal process called these dynamic efforts "postures," they were not intended to function as static or aesthetic poses to be mimicked exactly. Indeed, the shift in language from "pose" or "posture" towards "dynamic effort" speaks to the intended fluidity of these shapes. The actor is able to adjust the posture to their physical needs, and they are encouraged to explore movement within each posture by shifting the limbs to explore how both subtle and larger movements affect their experience within the tremor.

Throughout our Destructuring we would emit "fluffy sounds," an abstract vocal noise made by engaging the vocal folds with minimal effort ("Breathing Matters" 4). This action of voicing an unfocused, fuzzy sound served the dual purpose of reminding us not to hold our breath while also allowing us to release the vibrations of our sounds into the room. At times we were encouraged

\footnotetext{
${ }^{4}$ More recently termed as "dynamic efforts" (Papa et al. 1)
} 
to experiment with loosely voicing key words and phrases from any texts we were working on, as well as any words that evoked images that came to us as we Destructured. This free-associative approach to tremoring on text became the bedrock on which I explored Thea's inner world outside of the rehearsal room: tremoring allowed me to physically engage with Thea's lines as I learned them, while tapping into the spontaneous nature of the tremor led me towards imaginative discoveries that I might have otherwise overlooked.

If Destructuring serves the purpose of undoing any unnecessary physical and mental tensions or habits within the actor, Restructuring provides the actor with the resources to rebuild a healthy, resonant structure with which to support their sound. To do so, the actor engages their "focus line," an imaginative and sensorial tool that allows the actor to focus their energy and intention towards a listener or scene partner. Fitzmaurice describes the focus line as a line that originates in the pelvic bowl, runs up the spine through the third eye in the forehead, and then extends towards the actor's intended point of communication (Kotzubei 13). This marriage of abstraction, anatomy, and physical sensation transforms voiced sound into an action that extends beyond the boundaries of the body. The actor does not simply speak words aloud—through their sound waves they send energy along a trajectory that begins with the inner structures of their own body and lands on their partner. The cycle does not end there; rather, the partner receives this energy and transforms it with their own influence before sending it back to the original speaker, and so forth ad nauseum until the interaction ends. Actors who perform for live audiences have the added challenge of incorporating their audience into their focus line awareness, since the audience is receiving and interpreting the sounds emitted by the actors and returning their own impulses through their reactions (Papa et al 7). For all this to function effectively, the actor must develop a keen sense of awareness of the entirety of their focus line, both internal and external. To 
visualize the process as it originates in their own body, the actor can practice synesthesia, or the ability to "see feel." This requires the actor to extend their sensory awareness to the parts of themselves they cannot directly see-internal organs, muscles, bones, and parts of the body that they are not directly viewing at any point in time (Kotzubei 13). This requires anatomical knowledge of the breathing apparatus as well as a sense of imagination and play. Based on the sensations within their own body, the actor may describe their spine as a cooked noodle running down their back, for example, or the pelvic bowl as a literal bowl filled with water. The focus line itself can also be creatively rendered: the sound can become a ball of yarn that is tossed up the length of the spine and out the third eye, trailing its tail as it unwinds towards a partner, for example, or a drop of water that travels up a flexible-tube-spine and then glides through the air before splashing on the listener. These fantastical images can elevate focus line work from an uninspired push-pull of muscles for sound generation to a creative endeavor in which the actor can fully invest their mind, body, and emotional energy.

\section{Fitzmaurice Voicework ${ }^{\circledR}$ in the Rehearsal Room}

The mechanical applications of Tremorwork ${ }^{\circledR}$ to an actor's physical and vocal warm-up process might seem fairly straightforward, and the focus line has clear applications to partnered work in terms of straight-line communication. The question remains, however: how else can Fitzmaurice Voicework ${ }^{\circledR}$ be applied in the rehearsal hall when it comes to creative work?

Fundamentally, the voice is concerned with sharing. We speak and make sounds to communicate, and in doing so we share air, space, and sound waves with those around us ("Douglas Interview" 9). These vibrations can even influence a listener to vibrate sympathetically, similar to how a note played on a piano might cause the strings on a guitar sitting several feet away to hum ever so slightly (Kotzubei 4). Thus, our voices have physical impacts on the spaces we 
occupy, and when we meet to rehearse scenes from a play, we bring our vibrations into the room with us. This vibratory influence we exert on the space around us also returns to us, in the form of impulses sent from our scene partners. These little moments of give and take become the sparks that generate the cycling electrical current that makes theatre feel alive and human, pulsing and vibrant to the touch. The voice is an integral and visceral part of this power, this energy, we can release into the room as we tell a story.

Catherine Fitzmaurice defines emotion as a movement of energy, and more specifically, as a term we use to indicate physical sensations that come hand in hand with a psychological component. An emotional impulse can "live" in an area of the body and, if allowed, move through the system in response to some external stimulus (8). If we turn our sights towards a wholly scientific explanation of this, we find that person's emotional life and physical life coexist within one form and are regulated by the same systems: in fact, the autonomic nervous system, which regulates involuntary aspects of our survival such as our breath and heart rate, is directly responsible for eye movement, muscular tensions in the limbs, and shifts in vocal dynamics such as rate of speech and $\operatorname{pitch}^{5}$ (Van der Kolk 76). From this we can reasonably conclude that emotions are not just make-believe events that happen in our heads - they are highly physical responses to our environment that simultaneously ripple throughout our bodies and minds. Much like how an unrestrained tremor passes from the periphery towards the body's center, an unchecked emotional impulse can wave through the core of the body, causing us to laugh, cry, scream, or otherwise physically vibrate with some psychological current of energy. If we repress an emotion, however, then we experience the emotional equivalent of constricting a tremor: the muscles tighten, the

\footnotetext{
${ }^{5}$ Emotion is referenced even in the way that the autonomic nervous system is divided into the branches sympathetic and parasympathetic: that is, "for emotion" and "against emotion" (Van der Kolk 77).
} 
breath shifts and shortens to accommodate the added tension in the system, and the energy bottlenecks until it passes through the system some other way: by fading, by transferring into another action, or by exploding against the backpressure.

In Fitzmaurice Voicework ${ }^{\circledR}$ the actor is discouraged from relying on the tremor to generate emotional impulses. While it can prove effective for some, inevitably the actor will use the emotionally evocative nature of the work to create mechanical responses that are meaningless to their environment and the impulses they are receiving from their scene partners (Kotzubei 8). However, the actor can understand the relationship between the voice's ability to act on its environment and how emotion flows from that action. If the actor acknowledges that the voice is an energetic action, then they can begin to understand that it can be shaped through its primary energy source, the breath (6). From there, a performer can experiment with modulating and directing their breath into the form that best suits the character's given circumstances, with the understanding that if the breath, voice, and body are unimpeded, then the emotional life will follow.

With this in mind, we can direct our breath energy in several ways as we work in the rehearsal room:

Warming up: by using Destructuring in a warm-up sequence, we can create a sense of physical and mental preparation for the work to be executed in rehearsals. The tremors warm up the muscles and the voice mechanically while vibrating the brain into a holistic state of readiness ${ }^{6}$ to open our mind to the possibility of in-rehearsal discovery.

\footnotetext{
${ }^{6}$ As defined by Patsy Rodenburg in The Actor Speaks: "a heightened sense of being that is responsive to all stimuli around them" (Rodenburg 18).
} 
Partnered work: by engaging the focus line to both our scene partners and the anticipated audience, we invest in a genuine, reciprocal connection to the other people inhabiting the world of the play. We can also observe the effects of our breath and vocal energy on our scene partners and theirs on us.

Individual character exploration: between rehearsals we can perform both self-directed and guided explorations that implement tremoring alongside other forms of creative work such as guided meditations and free-associative journaling. Two such exercises that I used during this rehearsal process are described in the next sections.

\section{Trememoring through Thea}

Over the course of my voice studies, Professor Taylor introduced us to two key exercises that I carried into my exploration of Thea. The first, Trememoring, is a guided exercise that she learned under Cynthia Bassham, Lead Trainer and Director Certification for the Fitzmaurice Institute, during her Fitzmaurice Voicework ${ }^{\circledR}$ certification program. The second, Free-Associative Tremoring, Professor Taylor developed herself by pulling together influences of Meisner, stream of conscious writing, and elements of Destructuring.

We typically practiced the Trememoring exercise in groups, with Professor Taylor prompting us throughout. The actors are invited to begin in a tremor posture of their choice. At any point throughout the exploration the actor may release stream of conscious verbiage and sounds into the room, or they may simply choose to release fluffy sounds. The actor may also shift postures at will throughout the exercise to observe how the various questions and images from the prompts resonate in various parts of the body. After they have settled into their first posture, the guide directs the actors to envision their character as a toddler and to observe their character from a distance. After several minutes they are prompted to "step" into their character's toddler body, 
so that their perspective shifts from outside observer to a first-person view of their character's world. The actor-character is then shifted forward in time incrementally, and the guide prompts them to imagine biographical details such as their character's childhood best friend, first conflict with authority, first serious love, and then a moment where the character confronts a major decision that has just been made (perhaps one that contends with their entrance to the world of the play). Between each age exploration the actor is encouraged to briefly rest from their tremoring to jot down any notes, images, or experiences in their journal. They are also prompted to consider the areas of the actor's instrument where specific experiences might resound most strongly, so that they can explore where sense of love, trouble, friendship, or conflict might resonate within the body and shift postures accordingly. At the conclusion of the exercise the actor may choose to continue journaling about any experiences that struck them as compelling or poignant.

The exercise yields fertile imaginative territory for the actor to explore. Through the prompts they construct a past for the character that builds into the moments of their entrance into the play. This helps the actor to forge a sense of origin, context, and history for the character that informs their relationship to friendship, loyalty, love, authority, trouble, and life partnerships. The exercise also enables the actor to blur the lines between themselves and the character without dissolving them entirely. The actor steps into the character, fusing their disparate bodies and minds into one, yet the actor's own sense of self permeates their imaginings of the character's experiences. The exercise can also encourage the actor towards a more nuanced view of their character; an actor can shade a morose or villainous character with a sense of play and joy from the youngest ages of exploration, while an actor playing a jovial character might discover a sense of gravity in the feelings of trouble, love, or loss. The actor can then expand on these discoveries 
through journaling, so that they can continue to flesh out any interesting images or ideas as they continue rehearsals.

Through the Trememoring session led by Professor Taylor, I began to uncover some insight into Thea's younger years. I had already gleaned information from her adolescence forward through previous text analysis, but until this exploration I had not spent much time considering Thea's youth. As I travelled through her lifetime over the course of the prompts, I began to imagine Thea as a young girl with a context beyond her marriage and her relationship to Hedda. I created a young friend for Thea's six-year-old self, who I dubbed Marte, and I envisioned the two of them playing in a sunny, pastoral setting. I felt especially compelled by visions of rolling, grassy hills against a vibrantly blue sky, with a river gently burbling in the distance. I also began to envision an outline of Thea's parents somewhere in the background of this image. During the exploration of trouble and authority the scene abruptly shifted to a dark interior of a house where sickly-pale sunlight filtered through clouded windows. I suddenly saw a crystal bowl in my mind's eye, and as I let myself wander through the chaos of the tremors I began to build the story of this bowl. The room felt leeched of all color and furnishings, which created an aura of desolation and abandonment. I pictured the bowl shattering in this space, and suddenly the image of Thea's father, angry at the loss of this cherished item, flashed through my mind. They're moving, I thought, and the bowl was the one thing they had left. When I came out of the tremor I jotted down my impressions of the scene and added a few details to crystalize its significance. I quickly decided the bowl was important because it belonged to Thea's mother, who had died. The family was moving away from the happy, sunlit country towards the dingier southern capital. Thea's mysterious past was starting to feel tangible in my imagination. 
In continuing the exploration, I moved forward in Thea's life and began to flesh out moments that were hinted around or even discussed in the script, chief among them Thea's early relationship with George, her first meeting with Eilert, and the moment where she chooses to leave her husband. I pictured her first kiss with George during their teenage years taking place in a field behind their school building one fall afternoon, the scents of clover and dry grass haunting the air as the two shyly embraced for the first time. I stepped forward a few more years and saw Eilert standing in the Elvsted living room with his back to Thea as he gazed out a window. From where I stood, I could see his tousled curly hair and the worn spots on his jacket, and I watched him fiddle with his watch as he glanced around the room before slowly turning back to face me. The scene shifted forward to a moment several weeks later where Thea walked past the room where Eilert was tutoring one of the Elvsted children. Through the open door I saw the struggle between teacher and pupil over some homework problem, and when Eilert looked up and smiled in acknowledgement of my presence I was flooded with a sensation of warmth and hope. Some evening afterwards I saw Eilert approach Thea with a request for help, scattered notes clutched in his hands as he spoke in a fervent, hushed tone of this new work that he hoped to bring into the world. I began to build an index of their moments spent together creating the manuscript during afternoon teas when the children were outside playing in the garden and late at night after the house had gone to sleep. I felt her exhilaration at the freedom of their conversation as well as her sense of alertness and wholeness, as if she had woken up from a years-long sleep. Then, the moment of Eilert's disappearance: I imagined Thea sitting in the same living room where they had written together, this time staring up at a portrait of her husband as weak light spilled into the room in the early hours of the morning. I was overwhelmed with a cold loneliness at this image of Thea settling back into the stagnancy of her married life, with her husband looming over her in painting 
form from over the mantel. I felt a small crack form in Thea's psyche-I can choose to leave. I saw her brood over this thought until it festered into action. Pack, hide, train schedule, go go go. And with that, Thea was on her way to Christiania.

While this exploration helped to shade Thea's context overall, I was most drawn to the images of her early childhood in the countryside, an existence that was filled with light, color, and life. The color palette of these memories reminded me of the repetition of blues in ochres in many of the inspirational images I chose and how light had already unconsciously played a central role in my imaginings of Thea's life. I was also intrigued by the relationship between the snippets of the Thea's life and the postures in which I had tremored. As I wound through Thea's earliest memories, I had primarily explored arching positions, such as Rocking Horse and Healthy Cow, which had generated an energetic impulse that centered in my upper chest around my heart. This impulse had germinated into a sense of warmth, comfort, and curiosity that felt fitting for Thea's younger, happier years when she was less inhibited by the pressures of social status and personal survival. For Thea's teenage years I had shifted into Dying Cockroach, which had exposed my heart space to the room around me while transferring the origin of the tremor from my hands to my feet. This manifested feeling of vulnerability and yearning in my gut brain that fell in line with Thea's own desires for belonging, safety, and recognition. My final posture, Blue Bottomed Baboon, was a subliminally interesting choice, in that I usually used the posture as a method to transition from Healthy Cow into Standing Tremor when exploring the tremoring sequence on my own. I had unwittingly chosen this transitory posture to investigate one of the most pivotal decisions of Thea's life thus far. Each of these decisions had been unpremeditated on my part; I had simply chosen the posture that I wished to explore at that time without much forethought. Yet in looking back on this commingling of physical and mental exploration I couldn't help but notice 
how my choice in tremoring posture seemed to physically underscore the key moments of Thea's narrative journey.

\section{Free-Associative Tremoring}

While the Trememoring exercise requires a guide for the actor to follow, Free-Associative Tremoring can be executed completely independently. Because of the solo nature of this work, the actor has the freedom to cater the exploration to their own needs:

Stream of conscious journaling: the actor can tremor in one or several postures, then write a stream of conscious journal entry from the character's point of view. This was a technique I resorted to often, and usually I would decide on a key word, phrase, or inspirational image that I wanted to meditate on. I would write the phrase at the top of a blank sheet of paper, then I would Destructure for ten to fifteen minutes and allow myself to release free-associative babble associated with my chosen subject. After tremoring, I would immediately transition to writing by setting a timer for another ten to fifteen minutes and writing continuously in character on the journal page where I had written my key phrase/image until the timer sounded.

Recording the babble: the actor can tremor as in the above exercise, but rather than journaling their discoveries themselves they can solicit the help of a partner to record any words or phrases that they speak throughout their tremoring.

Taking the character for a walk: the actor can choose a line of text and tremor in different postures while releasing the text and any associations they make to it into the room. Between postures they can get up and begin to walk around their space, speaking the text and releasing sounds into the room. 
The actor is free to wander away from the text towards their own impulses and observations, but the text remains as a guidepost that can reground the actor if needed. Grounding themselves in the text allows the actor to begin physically embodying the lines as they memorize them, so that their exploration of the character's words and thoughts takes on a viscerally imaginative quality as well as a mental one. ${ }^{7}$ The actor also gives their imaginative meanderings a sense of reality as they speak their lines or any free-associative babble aloud, so that the images and words in their mind are drawn into a more concrete dimension where they can be explored and interrogated more thoroughly.

During one afternoon when I managed to snatch enough free time before rehearsal to roll out my yoga mat and try the Free-Associative Tremoring, I selected Thea's key phrase "I came to have a kind of power, almost, over him" as the basis for my meditation. After performing a tenminute Destructuring sequence I sat down to write a stream of conscious passage that hinged on this phrase:

I came to have a kind of power, almost, over him like electricity or a wave a shape/dimension of control no not control freer like wind or water unyielding like earth but foamy like the sea completely contradictory and unrefined, unladylike. And I'll never go back to not having this, this magic source of energy and light. I love him, but it's more than that. I want to be inside of him, his mind, his head, his heart, his body, to fill him in the same way that he fills me. He's completely changed my life and lifted me beyond the confines of my own spirit and the autumn leaves. We met one autumn day when he came to our doorstep asking for a job and my husband pitied him and gave him one. But I could never pity him - it felt too base for one who deserves more than servants' quarters and a salary. His mind is in the celestial dimension even as his body inhabits the earth and I have become his disciple, me, little Thea who was so meek and gentle with my long braid, a little flower but flowers wither and hair falls out. His book will be eternal and I will be part of that. The manuscript that we birthed together on quiet evenings when my husband was away, every opportunity left open for a tryst. But our kisses were imprinted on pages in ink, not on skin with lips. I became his mouthpiece, his hand, the curves of my writing giving structure to his thought as the children ran in the yard, unaware of the genius sitting

\footnotetext{
${ }^{7}$ In her classes Professor Taylor often references the "gut brain"- that is, the viscera, the area of the body that often reacts strongly to survival impulses. Over time I began to daydream that the gut brain might also have a gut imagination.
} 
at their dining room table editing their history homework. If only I could reach his heart as quietly, deftly as he has touched mine. I felt our kinship grow little by little, each cup of tea or orange slice shared over a page of writing building rungs to our ladder, taking us higher into the clouds until vision ceased to matter and we simply floated, blind, frozen, weightless, listening to the hum of the universe. He has given me what I could never give myself, made me understand what I deserve and made me more human. He has given me life, and I gave form to his book, like a mother gestating a sperm into full form and body giving weight and substance and cellular structure to what was formerly intangible.

I immediately reread the passage after finishing, and I found references to lines, phrases from rehearsals and discussions with the designers littered throughout, such as the image of Thea as a flower, which the head of the costume shop had mentioned in passing one day when I was being fitted for a costume piece. I also noticed repetitions from my earlier explorations with Trememoring: the autumn leaves, the moments when Thea and Eilert worked together late at night, the image of Eilert tutoring the Elvsted children, and the play of light as a source of inspiration. Most of all, I was struck by the sensuality of the text as it continued plumbing the metaphors of the manuscript as Thea and Eilert's offspring. The vivacity of my journal entry helped to fill in the gaps of Thea's presentation as a gentle and at times overemotional woman. In this version of Thea there was room for sexual longing, lofty goals, and all-encompassing love. I noted that much of the exploration still fixated on Eilert as the crux of Thea's worth, but it also provided imaginative context for their friendship's slow development around their shared work on the manuscript.

While I did not have the time to repeat this exploration with other key phrases or images from the play due to our busy rehearsal schedule, I would take the time to perform mini-free associative check-ins during my brief warmups before each rehearsal. Each night I would choose lines or words from the scenes that we were scheduled to rehearse and release brief spurts of stream of conscious babble as I tremored through my rehearsal preparations. The brevity of these checkins meant that I did not have time for a deep dive into Thea's psyche, but touching into previous discoveries and inspirations allowed me to incrementally build on any material I had uncovered in 
lengthier meditations and exploratory sessions. These quick snatches of free-associative tremoring served as an incubator for my imaginative development of Thea, so that each time I returned to the scene I could further invest in the possibility of discovering new facets to her character. 


\section{CHAPTER SIX: FORMING THE PARTS INTO A WHOLE}

We hit the ground running once we began the process of blocking the show. Our rehearsal schedule consisted of meeting six times a week: 7:00-11:00pm on weeknights, and 12:00-6:00pm on Saturdays. The week before tech coincided with the Southeastern Theatre Conference, and since most of the faculty responsible for graduate classes were out of town during that time the director added afternoon rehearsals during the studio hours with the graduate students and ran the show during regular rehearsal hours with the full cast. To say that the schedule was rigorous is a gross understatement: the graduate class lived and breathed the script for the seven weeks of the production, all the while attending our other classes, keeping up with homework, and performing our required assistantship hours.

I tried to ground myself within the chaos through my Fitzmaurice-oriented explorations of Thea. Prior to each rehearsal I warmed up using a combination of yogic techniques and tremoring, and I did my best to carve out time for the character exploration work I described previously. My intentions were noble in the beginning, but as the weeks dragged on and fatigue set in I found myself in the position of weighing the need to do more, to explore more against the need to give myself breaks to preserve my physical and mental health. Throughout I managed to cling to a routine of tremor warmups and to sneak time for character meditations between classes and rehearsals. Progress in and outside of rehearsals sometimes seemed to come haltingly, yet still it came, until bit by bit I managed to pull a living, breathing version of Thea from the text.

\section{Building Character Relationships}

Early in the process Robynn established the importance of text work, and as rehearsals progressed the notes reflected her attention to text delivery. From the beginning she made sure to draw the cast's attention to rate of speech and clarity of pronunciation as well as to the punctuation 
provided in the text. Given the text's spareness, I found punctuation key to beginning to develop ideas of Thea's background that are not discussed openly in the dialogue.

The first mystery I aimed to resolve for myself was that of Thea's relationships to and opinions of the Tesmans, and I was pleased to see that within the first several rehearsals Robynn had dedicated a chunk of time to allowing Nicole Smith, who played Hedda, and I to explore the section of the first act when Thea and Hedda interact alone. Two key elements that I felt was still missing from Thea's background were an idea of her social status during her time in school alongside Hedda and George and a clear picture of whether Thea is aware of when she is being manipulated by Hedda. To the first point, I found an answer in the text immediately after Thea is gently reminding Hedda of her schoolyard bully days:

HEDDA: Really? Did I do that?

MRS. ELVSTED: And once you said you'd like to burn it off. HEDDA: Oh, that was only in fun.

MRS. ELVSTED: I was so silly in those days. And then, afterwards-I mean we've drifted so much apart. Our backgrounds were so different, I mean (Ibsen and Turner 20).

As we walked through the scene, I noticed that pause following "afterwards," and I began to wonder at the possibilities of its meaning. During a short break when Robynn was giving us notes we discussed the significance of this sudden shift, and together we developed the idea that perhaps the pause was a moment of redirect. In that moment, maybe Thea was withholding herself from giving too much information away that might tarnish her newfound friendship with Hedda, instead continuing into the more diplomatic observation that they came from differing social backgrounds. At this, I found another clue: Thea was from a different, and in all probability lower, social 
background than Hedda, who was born an aristocrat's daughter. This is the sole reference that Thea makes to her family history in the play; she never mentions any relatives, including parents or siblings. On top of this, she subtly notes some major shift in her life with the word afterwards, which made me wonder: after what? Was there a major, unsavory event in Thea's life during her school days that drastically changed her fortunes for the worse? With this I began to work out an imaginative narrative that accounted for the gaps in Thea's story. Thea was likely an orphan, or perhaps simply raised by a non-parental relative — a maiden aunt, I decided. This aunt would have cared for her, clothed her, and provided her with an education, and perhaps Thea and this aunt were close, but something happened to remove Thea from the aunt's influence towards the end of Thea's school days, such as the death of the aunt. Without an inheritance or someone to provide for her, Thea was forced to seek out work, which would have plummeted what little social status she previously had claim to. Additionally, this would have effectively ended Thea's relationship with George, as she would not have been a suitable economic match for a would-be scholar. So, in need of income and willing to take any opportunity that helped her support herself, Thea accepted a governess position shortly after finishing school and travelled to the Elvsted residence to care for the family's children, and then their ill mother, before eventually marrying into the family once the mother died. As I sketched out this narrative for Robynn, she pointed out that this would mean Thea would have another connection to George, in that they were both raised by doting aunt figures.

I continued to toy around the idea of Thea's recognition of Hedda's bullying through rehearsals. Robynn encouraged Nicole and I to explore the levity in the moment, especially in regard to Thea reminding Hedda of past transgressions. Rather than leaning into a scolding or adversarial tone, she suggested that I try to consider it a self-deprecating anecdote, as if Thea was 
almost shrinking herself as she spoke the words to Hedda. Within this I began to play with the idea that Thea was waffling around with the contrast between her memories of Hedda as a bully and the present image of Hedda as a caring and concerned hostess. The lines referencing the hair pulling and burning began to feel more like questions, as if Thea was struggling to play it cool in front of the aristocratic and formidable Hedda while some survival instinct leftover from her adolescence rang the alarm bells that she was in the presence of danger. I found that this trajectory cut a clearer path to Thea's self-dismissal in "I was so silly in those days," since it created a narrative where Thea was already questioning her own memory of the events as skewed while failing to recognize that Hedda was playing chess with Thea's self-image. This also created a natural build into the "And afterwards_-" as if Thea was ramping up to overshare with Hedda before realizing the danger in such a mistake and backtracking to safer territory. The more I walked in her shoes, the more I began to recognize that her ability to dismiss Hedda's past treatment of her and move directly, if hesitantly, to a first-name basis with her former tormentor invoked her hunger for companionship and belonging, something that even Eilert had not been able to provide her during her time in the Magistrate's household.

The rehearsals began to fall into a pattern early on: experiment with blocking in the first run of the act, run the blocking at the next meeting and fine-tune specific notes from the director, then move on to the next act. I began to notice over time, however, that after initially blocking the second act we kept returning to run parts of the first, with the notes becoming more attuned to specific details of movement, vocal inflection, and intention. I appreciated the repetition at first, as it provided the opportunity to retread familiar territory and seek new discoveries. Then, our first planned stumble-through of the show's first half hit a snag. I had begun to note more and more frequently in my journal that I was feeling the drain of the rehearsal schedule, and this particular 
day I was doing what I could to further my previous work while trying to keep my energy up. As we progressed through the first act, the cast noticed that we were missing an actor, and stage management apparently could not get in contact with him. Eventually the actor showed up, and Robynn stopped the rehearsal and called the cast into the room to speak with us. She announced that rehearsal would be cancelled for the rest of the evening and that she was disappointed with how the cast's overall dependence on looking at our texts prevented us from making intuitive progress with the narrative of the story. She turned to some of the cast and apologized to us for releasing us before she had a chance to let us work, and I remember blearily and nonsensically replying, "no, thank you" as I collected my things. Frankly, I was thankful for the opportunity to eat a hot meal and sleep.

In the blocking rehearsals after this upset I began to notice that Robynn's tendency to backtrack and correct specific moments from scenes we had previously blocked and tweaked recurred more and more frequently, with specific attention to the first act of the play. Each time we ran a previously blocked section I tried to invest further in the details of Thea's narrative arc. In the first act I delved deeper into my relationships to Thea's given circumstances, including puzzling out her relationship to her husband, who was only ever acknowledged as "the Magistrate" or "Mr. Elvsted" in the script. It seemed to be wholly a marriage of convenience, in that Thea never discusses any form of emotional connection to the man, saying "we have nothing in common," and later describing him as someone who “doesn't love anything except himself. And maybe the children, a little" (22). From this I began to envision a man consumed with his work and completely unconcerned with his family, to the point of paternalistically assuming that the governess he hired for his children can double as a nursemaid for his sick wife and later as a replacement spouse. Thea even says that she "thinks he finds me useful" (22), like she is an energy-saving household 
appliance. I wondered if Thea had hoped for his affection at one time, maybe immediately before the marriage, or if the wedding had been a shrewd method for her to rise through the social ranks to a point where she could obtain a small sense of freedom at the price of her mobility and independence. These reflections crystallized the leadup to Thea's decision to leave her husband for me, and reinforced the idea of Thea as the sort of person who, given a set of circumstances that no longer suit her needs, is willing to walk out the door, even if it means sacrificing means for a passive, socially acceptable survival.

When we started to block the second half of the fourth act we immediately stumbled into a stylistic challenge. While Ibsen's modern reputation has seen him colloquially dubbed as the "Father of Realism," nearly all his texts bear some echoes of their theatrical forebearer, the Victorian melodrama, a formulaic rendition of the "well-made play" that typically indulge in larger-than-life emotions as their characters battle with some force greater than themselves (Gilmour 345). George Bernard Shaw notes in The Quintessence of Ibsenism that what differentiates $A$ Doll's House from its predecessors is not the absence of melodramatic archetypes throughout the play, but rather Ibsen's choice in the pivotal final moments to allow Nora to transcend her typecasting as the tragic heroine so that she can sit down and hold a rational conversation with her husband about their issues (Shaw 219). Hedda Gabler navigates further still from melodrama as a whole, but its echoes can still be found in the text's final act when each character seems to conveniently enter one after another, each bearing more terrible news than the last. Throughout our rehearsal process, in what I surmised was an effort to encourage the cast to ground ourselves in the given circumstances of the play, Robynn would insist that Hedda Gabler was not a melodrama. I struggled privately with this idea in rehearsals, as Thea's stage directions often require her to resort to emotional hysterics within seconds of any major revelation concerning 
Eilert. For the most part Robynn would ask me to ignore these directions, which I was usually glad to do, but at times I found that interpreting the scenes through a melodrama-free lens necessitated extra acting acrobatics to create a sense of cohesion to Thea's emotional through-line in the absence of the original stage directions. Then we began to stage the final act, and the formula of each character heralding increasingly tragic information at precisely the right moment forced us as an ensemble to reckon with the play's relationship to melodrama. After trying to coordinate the blocking to work with the shifts in the text, Robynn started to cut words, stage directions, and whole lines from the script to lessen the scene's mechanical nature. I was amused and thankful to see some of the changes, as it saved me from having to find a way to sell the line "How dreadful!" as a response to Eilert's death without seeming absurd, but even with these changes it was a challenge to work with such an antiquated text to ground the scene in the gravity of Eilert's suicide.

After weeks of blocking and re-blocking we began to run the show, which allowed the cast to take stock of the larger picture of the play's narrative as we neared tech week. Around this time Professor Taylor offered us a chance to participate in a guided character meditation, and I began to carve out what little spare time I had before rehearsals to practice the Free-Associative Tremoring exercises that we had learned in our voice classes. Each time I came to rehearsals after one of these sessions I would try to carry my character discoveries into the room with me and weave them into the narrative of Thea's story. As with the unspoken details of Thea's relationships to the other characters onstage, the audience would never explicitly see any of these narrative details play out, but each nugget of information helped me to ground Thea as a fully realized human with experiences, desires, feelings, and a sense of history. 


\section{Thea's Tears and the Curse of the Corset}

As I integrated personal and communal character work through rehearsals, the physical shape that I took on as Thea began to morph from my own natural posture. I uncovered a softness and lightness within Thea's earnestness and delicacy, and in time these qualities began to trickle into her body and voice. Her footsteps became softer, and her arms were buoyed up slightly as if supported by cushions of air. I also began to notice that my median pitch drifted upward slightly and that I was unconsciously leaning towards a musical, lilting prosody that dwelled in a higher range than my typical speaking voice. In early rehearsals I felt that my sound and physicality were fully embodied and emanated from the spine of Thea's being in a logical and intuitive way, but as rehearsals progressed and fatigue began to set in, I began to default to unsupportive habits within these artistic choices. On the worse nights I would collapse slightly into the front wall of my corset and droop my shoulders forward, which would restrict my abdominal muscles. This in turn restricted my breathing, which severed my vocal and physical connection to my lower body. On these nights my voice often felt "stuck" in this higher, more musical register, and my delivery felt mechanical or even superfluously florid rather than connected to the intention of Thea's needs and desires in the moment. Professor Taylor observed our Crew View rehearsal, and in her notes she referenced the physical and vocal dissonance that had already begun to ferment and itch in the back of my mind. She offered the feedback of grounding myself in Thea's sense of truth and allowing that impulse to recenter myself in the core of Thea's identity. I remember receiving the note and immediately bridling at how the note's introduction was framed around Thea's voice being higher pitched. In a moment of unhealthy actor ego, I rifled through my memories of discussing Thea's character with Professor Taylor and recalled how during one of our chats about the show she had mentioned Thea as being a feminist character, and had tied this to a sense of 
strength, grounding, and depth of connection to the breath and voice. Well, this is clearly a difference of character interpretation, I mentally retorted as Professor Taylor gave notes to another actor. A character can be feminist and still be light and delicate. I was stewing by this point, and even as I self-righteously mounted my silent self-defense, a niggling part of my brain plaintively insisted that maybe, just maybe the reason the note bothered me so much was because it had hit on something I was struggling with, and that instead of being grateful that an outside eye had put a name to the issue, I was receiving the note with the sting of oh, I should have thought of that. I also began to reflect on the nature of Thea's sense of strength within this delicacy I had been experimenting with. Had I moved in a wrong direction? Was I stifling the character's story by presenting her as a wide-eyed damsel out of turn? I thought about this for a few days, and in that time, I came to the conclusion that Thea can absolutely exist as delicate, feminine, and perhaps unfeminist by modern definition. The text fully supports her as demure and hesitant, and I had found a path through those qualities that, on a good day, felt rooted in a sense of truth for her character. I also considered for a while what it means to interpret a character as being a "strong" woman, and how often we socially prescribe traditionally "masculine" qualities (deep voice, authoritative presence, directness, self-assurance) onto female characters and assume that those qualities alone project strength. However, to create a fully realized character of any gender we have to acknowledge the full human potential for that character to have vulnerabilities and moments of weakness, or even personality traits that are not considered sympathetic or likeable. The truth in presentation came in crafting a version of the character whose actions made logical, human sense in their environment. Finally, I returned to Professor Taylor's note and came to the shame-faced conclusions that 1) I had extrapolated the note well beyond its original intention and 2) I was deflecting from the need to address a real and present issue that ran the risk of becoming 
habitual if not put in check. I also reminded myself that Professor Taylor was well aware of my physical and vocal habits after nearly two years of working with me in the classroom and in the rehearsal hall, and that resultantly she could pick up the cues of when I was defaulting to comfortable territory rather than challenging myself to move to more fertile artistic ground. I resolved to get over myself and to be more mindful of doing an energetic, full-body warmup before rehearsals so that I could avoid the forward collapse into my corset.

I also found that the corset presented a challenge in the vocal extremes required in the text. Acts II, III, and IV all had moments where Thea cried or expressed some emotional response to extremely difficult events. I often had only a few lines of buildup to get to these places, so I would remind myself just before going onstage for these scenes of the given circumstances leading into the scene: what information I had just found out, what had just happened, what I did not know yet, etc. Once I had built the narrative gateway to these confrontational moments, the challenge came in how to express these emotions in a vocally and physically healthy way, and the addition of a semi-rigid corset only heightened this conundrum. Usually expressing vocal extremes, such as laughter, crying, or shouting, requires that the actor fully engage with their abdominal muscles and their connection to their spine so that they can breathe into those deep, vulnerable places in their gut-brain where deep, primal emotions are housed, but in my case, I was wearing a support garment that renegotiated my alignment with these parts of my body. On top of this, the moments of heightened emotion all came in the middle and end of the play, and while we had run the first act many times in rehearsal we had spent significantly less time on later scenes, which left me fewer opportunities to explore how best to navigate these moments healthily. I discussed these challenges with Professor Taylor when we explored vocal extremes work in class a few weeks before tech, and she advised that when I explored Thea's grief, which would require me to engage in a sense 
of forward collapse, to focus on the sensation of my heart sinking or falling into my center rather than physically rounding myself forward. This way I could engage with the sense of collapse without cutting off my connection to the lower half of my body. I continued to experiment with this concept and found the image of my heart sinking helpful, but I never was consistently seamless in how I engaged with the moments of crying and grief from night to night. I eventually began to settle into the scenes over the course of tech week and felt comfortable grounding myself in the idea of listening and responding to the impulses offered by my scene partners in the moment, but still missed the opportunity to explore and fine-tune those moments in greater detail during rehearsals.

\section{Conversations with the Director}

During rehearsals I decided to sit down with Robynn and interview her about her approach to the play and to get further insight into her directorial approach to Hedda Gabler. We managed to find time in the days prior to the show's opening. The following is excerpted from our conversation.

M: Punctuation has been such an important part of our rehearsal process. What is the origin of your noticing that it was so tied to acting and intention?

R: You really have to pay attention to it. Any kind of verse drama you really have to think about about it. I had incredible voice and text people that I worked with in school and incredible master voice and text people that I've worked with professionally as an actor, and they can tell me things that directors can't. So, I've learned as an actor that my emotional life is completely connected to breath, and punctuation on many levels is going to tell me how much breath I get or how little.

M: It's interesting because we've been working with Brianne [Professor Taylor] over the past two years, and the Tremorwork ${ }^{\circledR}$ and Fitzmaurice Voicework ${ }^{\circledR}$ are tied to breath. And 
when [the graduate students] were studying classical work last semester, Brianne was really invested in making sure we noticed punctuation. A comma is different from a semi-colon, is different from a colon, is different from a a period. There's so many stage directions in punctuation. It's interesting to work on classical texts and then move into what is technically nonclassical but still has a sense of classical.

R: Yeah, I mean, it's everything. You look at a phrase in a Shaw play or in a more contemporary playwright like Tony Kushner or David Edgar, writers where you look at a paragraph that is a sentence, and you've got some decisions to make about where you breathe and how you keep that thought in here. And it's kinds of a brilliant exercise and certainly with Shakespeare, I mean, rules are made on many levels to be broken. If you're not going to observe that punctuation, answer why. What is the emotional reason that you drive through to the end of the line as opposed to taking that pause? I find those clues invaluable, certainly as an actor, but as a director as well.

\section{M: Do you find working with a translated text that it becomes even more important?}

R: Translated texts can kind of morph in a way. I've worked with a lot of directors who work on translated text where they take a lot from all these different ones, too. I had a couple of times working on Chekhov plays, where the director I worked with in Ashland, Libby Apple, did the adaptation, but she worked from a literal translation, and the woman, Alison Horsley, who did the literal translation. Alison was in rehearsal the entire time. So everything about it, you know, Jerry Turner, who did our Ibsen and who I worked with as an actor on two Ibsen plays. Jerry, often in rehearsal because he was the adaptor and the translator, would say, "Let me fix that for you. That doesn't sound like it comes from you." And it was always so interesting. He was tweaking his adaptation translation to fit the actor in the role. 
M: Hedda is a title character in a time when title characters were not often female. I'm really interested in your perspective as a female director coming to a play written by a man about a woman who is so dynamic. People keep coming back to this show even though it's 100 years old. Do you have any thoughts on that?

R: Well, boy, she is an enigma. She's a hard nut to crack, and a hard person to like. And what I love about Ibsen's writing is that it is so without sentiment, and that his characters are all incredibly human, with incredible potential, many, many virtues, and who have flaws, who have failings as human beings, as we all do. We live in an interesting time burgeoning in artistic leadership, not only in regional theatre and in New York commercial theatre, but even in film, you have more women in leadership roles that come to these plays. I've seen plenty of these plays directed by them that were brilliantly done, and I've worked with enough men who as directors and actors whose feminine aspect is very, very developed. But I think this is a really incredible time for women, and women in the arts in particular. To not only have our voices heard, but to offer up an aspect of leadership positions that, I wouldn't say is markedly different. But we're not men. We're going to come to it from a very specific place. And often that place is deeply experiential. That we have had a friend like that, that we've had those experiences.

M: I remember you saying at the auditions that Thea was the bravest woman in all of Norway, and that was just something that really, really resonated with me as I was going through auditions and callbacks. Where does this thought come from?

R: When I was young, I often played the best friend. I played Celia, and I aspired to play Hero. Lucetta to Julia, you sort of look at the best friend or the acquaintance to tone of the main women. And you think, for Hedda to be threatened by Thea, for Rosalind to rely so completely on Celia or Beatrice on Hero, that those characters are not to be dismissed, that they are worthy of the 
relationship they have with that dynamic principal character. And so my feeling was, why are they often written off? Why is Thea often written off as neurotic? Neurotic? The person who walked away from everything? Hardly. I think she's formidable. She's a survivor. She's going to outlast Eilert Løvborg, Mr. Elvsted, and Hedda. She and George Tesman are going to create an amazing life as partners, as equals, as helpers in each other's work. She may write her own book someday. Plus, I want the play to come from someplace vital. And how are we making vital choices for people who are insubstantial? I don't think Ibsen wrote an insubstantial person.

\section{Tech Week and Performances}

After weeks of rehearsal we finally reached the home stretch. Tech offered us the chance to finally step into the layers of our period costumes, from corsets and petticoats to jewelry and wigs. While overall the final leg of rehearsals ran smoothly, by this time the cast's energy was ebbing and flowing with the addition of new elements and the overarching exhaustion of working nonstop for weeks. Gradually Robynn's notes started to get sparser as she handed the reins of the show over to us and the stage manager. Through it all I tried to find balance between the lastminute adjustments and my need to tell my character's story.

Opening night welcomed the audience into our space, and for the first time I realized the challenge of playing Ibsen in a sunken thrust. This was a non-issue during rehearsals when the seats were empty, but suddenly I was addressing lines to people's knees and alarmingly aware of how much of the light spilled onto the front rows of seats, effectively welcoming their occupants into our playing space. The effect was jarring for a play that depended so much on the idea of slice of life drama, and between scenes I pondered the hilarious conundrum of how intrusive the audience felt to a process that had been, by its very nature, catered to the idea of showcasing our 
work specifically for spectators. I soldiered through the distractions and did my best to mentally lean into the set pieces for added grounding to avoid losing my focus.

With each performance we relaxed further into the foundations of our work, and while each night brought challenges of differing audience reactions and shifts in the group's energy we managed to finally cut loose and enjoy the fruits of our labors. Finally, we were able to communally trust that the work we had done was enough (or in the very least, would need to suffice) to fill the performance space with the story we'd crafted. Throughout the performance run I mentally danced between moments of truly sinking into the world of the play and allowing residual doubts about my commitment to character, breath, and intention to pull my head above the surface. After the third performance I noted in my journal:

Ah, the dangers of slipping into a prescriptive, overly technical mindset. Nights like this remind me that at any level of experience or training these things happen, and the measure of a professional is how you work through [them] and learn from the mistakes so they don't become habitual.

I would notice throughout the performances small moments of physical collapse, an easy thing for a tired actor wearing a corset to do, so I developed a ritual of checking in with my breath between scenes and meditating on inspirational images just before going onstage. I returned to the house tucked away in the autumnal forest, the woman bent over her writing table in the lamplight, and as the electric flash of the tangled lightbulbs. While picturing these images in my mind's eye I would take a moment to envision the length and flexibility of my spine underneath the layers of costuming as I allowed my breath to trickle into my abdomen. Over time I noticed that I was discovering new associations with each of the images, as if my continued investment in breathing life into them was remolding their significance to Thea's story. The little house buried in the red and golden foliage began to resonate within the idea of Thea's power over Eilert, as did the image 
of the lightbulbs. I also found the practice of checking in with my breath useful for times when my inner critic reminded me of an old note in the midst of a scene: moments when my prosody was too predictable, or my resonance trapped too high, or I made a cross or a gesture a hair too late. As I realized that I was slipping into an inner world of self-judgment I would make a concerted effort to re-engage with my scene partners and breathe along my focus line towards them, so that I was actively listening and responding to them rather than mentally scanning through a checklist of notes as I performed.

Just as the cast was beginning to experience a collective synthesis of energies, disaster struck. We were approaching the final two performances of the run, and suddenly Nicole Smith, the actor playing Hedda, fell ill and lost her voice entirely midway through a show. An understudy had to be sent on to finish the performance, and the next night, our closing performance, was cancelled. For my part the cancellation was timely, as the night of what would have been our final performance I lost my voice as well. Neither Nicole or I showed symptoms of any apparent illness, and we concluded that it was likely the stress of the semester finally catching up to us. Days later, the country shut its borders as stories of a deadly respiratory virus broke like a tsunami across the news cycle. 


\section{CONCLUSION: DECONSTRUCTING PROCESS}

This turned out to be one of the most unusual and hectic rehearsal processes that I have been a member of, on both a professional and educational level. Looking back, it seems we were doomed from the start to be short on time, given that casting and the delivery of scripts happened so close to the beginning of rehearsals. As an ensemble we struggled against the push-pull of the

professional expectations of our guest director and the number of hours in the day for us to memorize lines, eat, and sleep in the few hours allotted to us beyond rehearsals and class. Rereading my journal entries from the midpoint through the end of rehearsals elucidated for me how fatigue-drunk I became at points; the nearer tech loomed, the more often I left notes for my future self about how anxious, self-dubious, and above all how tired I felt. Looking back, my overarching question would be the efficacy of the six-day rehearsal weeks. Was it all worth it? Would the show have been better or worse if the cast had been allowed to rest and absorb instead of running segments of the play on repeat, literally to the point of illness?

Despite the challenges posed by lack of rest and free time, there were some bright spots. I had the benefit of exploring a character, who is often overlooked in her own narrative, under the guidance of a director who respected her relevance to the story, and I was afforded the opportunity to experiment with techniques in character development under the mentorship of a Fitzmaurice practitioner. The schedule was unsustainable, unbalanced, and unhealthy, but we survived the experience and built a play around it.

Immediately after our premature closure the students went home for spring break. Days later the nation began locking down against the first wave of COVID-19. The initial optimism of "this will blow over quickly" faded as the school shifted from an outwardly cheery extension of the spring holiday towards an ultimatum that all classes would shift online through the end of the 
semester. One semester turned into two, and as I type this nine months later I am facing the possibility that my final semester of graduate school will be online as well. In the space between Hedda Gabler and the present moment the world has radically shifted, and the nature of theatrical performance has changed with it. I cannot currently predict when I will be in a rehearsal room sans mask and social-distancing mandates, nor when I will perform for a live audience packed elbowto-elbow into folding auditorium chairs.

In a bid to keep audiences and participants safe from the virus many conventions and theatre companies shifted their materials and performances online. Suddenly I had virtual access to play performances and seminars that would have been too remote or expensive for me to attend in-person. One such resource was a three-day Fitzmaurice Online Summit offered at the beginning of August, completely free of charge for a brief period of time. I jumped at the opportunity to attend. The majority of the speakers were practitioners who taught at the university level, so many of the sessions were devoted either to their research or to discussions of pedagogy with the work rather than personal character development, but during a video where Helena Walsh, European Director of the Fitzmaurice Institute and an Associate teacher of Fitzmaurice Voicework ${ }^{\circledR}$, was being interviewed by fellow Associate Teacher Benjamin Mathes, I made note of a comment that Walsh made about experiencing opposites simultaneously as conceptual and experiential. As I watched the video, I commented in my journal:

Interesting framework to describe how the body can often evade definition, or easy definition in the very least. Everything we own/carry/think/know lives within us at the same time - the biological and the metaphorical coexist.

I reflected on this coexistence in the days after the summit, especially in relationship to Hedda Gabler. Thanks to the pandemic, the cast had been denied the opportunity to regroup and process our experiences with the production communally. Until this moment I had not fully realized how 
much I had needed to acknowledge the phenomenon that Walsh was discussing: the coexistence of positive discoveries and frustrations in those seven weeks, the satisfaction of working with a director whose holistic view of the play enabled me to delve into a sweet and soft, yet complex character juxtaposed against the challenges of working with a director whose process was so exacting that it became restrictive.

I was looking back through my notes from the week of performances when I rediscovered a small moment that I had shared with Professor Cathy O'Dell after opening night. After the performance we were chatting in the lobby, and as she described her reaction to Thea, she said, "What a great role." Something in the way Professor O’Dell phrased her comment resonated with me, as if she was realizing how much she enjoyed the character after seeing our production. As I reread this anecdote, I remembered how proud I was in that moment to have experienced the privilege of bringing a version of Thea to life that caused even seasoned actors to step back and admire her place within the larger story. In one of our final classes before Robynn left, she gave an impassioned speech about how we should speak the words of a play like our lives depend on it, because the lives of our characters do. They only exist insofar as we let them, and conversely, they have nearly as much infinite possibility in their narratives as any living human being does. Through the process of performing this role, I had experienced the gift of working in an environment where Thea's life was seen as worthy and complete as anyone else's onstage, and where she could transcend the confines of both artistic and academic stereotype. 


\section{BIBLIOGRAPHY}

Anthony, Katharine Susan. Feminism in Germany and Scandinavia. New York, H. Holt and Co. HeinOnline, https://heinonline-

org.wvu.idm.oclc.org/HOL/Page?handle=hein.peggy/fegesca0001\&collection=peggy. Accessed 19 Feb. 2021.

Armstrong, Eric. "Voice \& Speech FAQ." Voice \& Speech Source, https://www.yorku.ca/earmstro/res/qanda.html\#5. Accessed 19 Feb 2021.

Bryden, John, et al., editors. Northern Neighbours: Scotland and Norway since 1800. Edinburgh University Press, 2015. JSTOR, www.jstor.org/stable/10.3366/j.ctt14brzf1. Accessed 29 Nov. 2020.

Cardullo, Bert \& Robert Knopf, editors. Theater of the Avant-Garde, 1890-1950: A Critical Anthology. Yale University Press, 2001. JSTOR, www.jstor.org/stable/j.ctt1njm81. Accessed 29 Nov. 2020.

Cole, Toby, \& Helen Krich Chinoy. Actors on Acting: The Theories, Techniques, and Practices of the Great Actors of All Times As Told in Their Own Words. Crown, 1970.

Cole, Toby. Playwrights on Playwriting: The Meaning and Making of Modern Drama from Ibsen to Ionesco. Introduction by John Gassner. Hill and Wang, 1968.

Collett, Camilla. "Norway." Woman Question in Europe. Theodore Stanton, editor. New York, G.P. Putnam's Sons; etc. HeinOnline, https://heinonline.org/HOL/P?h=hein.peggy/womquep0001\&i=206. Accessed 19 Feb. 2021.

Cultice, Wendell W. "The School System of Norway." The Clearing House, vol. 42, no. 2, 1967, pp. 119-121. JSTOR, www.jstor.org/stable/30183285. Accessed 29 Nov. 2020.

Dahlmann, LA. "Norwegian railway history; the pioneer era 1851-1868; Norway." Talk Norway, https://talknorway.no/norwegian-railway-history-the-pioneer-era-1851-1868-norway/. Accessed 29 Nov 2020.

Finney, Gail. "Ibsen and Feminism." Cambridge Companion to Ibsen, S. 89-105, 1994.

--. Women in Modern Drama: Freud, Feminism, and European Theater at the Turn of the Century. Cornell University Press, 1989. JSTOR, www.jstor.org/stable/10.7591/j.ctvv413q8. Accessed 19 Feb. 2021.

Fitzmaurice, Catherine. "Breathing is Meaning." 1996. https://static1.squarespace.com/static/5569e19fe4b02fd687f77b0f/t/5a754aaac830259c53 8410f6/1517636267248/Breathing+is+Meaning+2018.pdf. Accessed 19 Feb. 2021. 
--. "Breathing Matters." 2015.

https://static1.squarespace.com/static/5569e19fe4b02fd687f77b0f/t/5a7d463a0d9297b92

8703650/1518159418798/Breathing+Matters+2018.pdf. Accessed 19 Feb. 2021.

--. "Structured Breathing." 2002.

https://static1.squarespace.com/static/5569e19fe4b02fd687f77b0f/t/5a754892c830259c53

83c803/1517635731086/Structured+Breathing+2018.pdf. Accessed 19 Feb. 2021.

Fitzmaurice, Catherine \& Eugene Douglas. "Interview with Catherine Fitzmaurice.” 2004. https://static1.squarespace.com/static/5569e19fe4b02fd687f77b0f/t/5a754963085229a61 61 ecdb6/1517636311816/Douglas-Fitzmaurice+ActingNow+Interview+2018.pdf.

Accessed 19 Feb. 2021.

Gilmour, Michael. "Victorian Melodrama: Victorian Melodrama." Literature Compass, vol. 12, no. 7, 2015, pp. 344-357.

Gray, Ronald. "Ibsen, Henrik (1828-1906)." European Writers: The Romantic Century, edited by George Stade, vol. 7, Charles Scribner's Sons, 1983, pp. 1421-1447. Gale eBooks, https://link-galecom.www.libproxy.wvu.edu/apps/doc/CX1386900152/GVRL?u=morg77564\&sid=GVR L\&xid=cecbb0d2. Accessed 29 Nov. 2020.

Hossain, Amir. (2016). "Ibsen's Treatment of Women.” Journal of Socialomics. 05. 10.4172/2167-0358.1000153. Longdom Publishing SL, https://www.longdom.org/openaccess/ibsens-treatment-of-women-2167-0358-1000153.pdf. Accessed 29 Nov 2020.

Hacht, Anne Marie, et al. "Ibsen, Henrik." Gale Contextual Encyclopedia of World Literature, vol. 2, Gale, Cengage Learning 2009, pp. 826-830. https://go-galecom.wvu.idm.oclc.org/ps/retrieve.do?resultListType=RELATED_DOCUMENT\&userGr oupName $=$ morg77564\&inPS $=$ true \&contentSegment $=9781414448718 \&$ prodId $=$ GVRL\&i sETOC=true\&docId=GALE $\mid$ CX2507200251. Accessed 29 Nov. 2020.

Ibsen, Henrik \& William Archer. Hedda Gabler ; the Master Builder ; from Ibsen's Workshop, Notes, Scenarios, and Drafts of the Modern Plays. Jefferson Press, 1912. Hathi Trust Digital Library, catalog.hathitrust.org/api/volumes/oclc/8820549.html. Accessed 29 Nov. 2020.

Ibsen, Henrik \& Jerry Turner. Hedda Gabler. Oregon Shakespeare Festival, 2003.

--. The Plays of Ibsen. Oregon Shakespeare Festival, 1999.

Ibsen, Henrik. The Correspondence of Henrik Ibsen. Edited by Mary Morison, Haskell House, 1970.

Kotzubei, Saul. "Interview of Catherine Fitzmaurice.” 2005. https://static1.squarespace.com/static/5569e19fe4b02fd687f77b0f/t/5a754b3453450ac909 
19a32c/1517636405310/Fitzmaurice-Kotzubei+Interview+2018.pdf. Accessed 19 Feb. 2021.

Lacey, Stephen. British Realist Theatre : The New Wave in Its Context 1956 - 1965, Taylor \& Francis Group, 1995. ProQuest Ebook Central, https://ebookcentral.proquest.com/lib/wvu/detail.action?docID=180010. Accessed 19 Feb. 2021.

Lauglo, Jon. "Populism and Education in Norway." Comparative Education Review, vol. 39, no. 3, 1995, pp. 255-279. JSTOR, www.jstor.org/stable/1188908. Accessed 29 Nov. 2020.

Maddison, Isabel. Handbook of British, Continental and Canadian Universities with Special Mention of the Courses Open to Women Compiled for the Graduate Club of Bryn Mawr College. New York, The Macmillan Company. HeinOnline, https://heinonline.org/HOL/P?h=hein.peggy/hbccunis0001\&i=1. Accessed 19 Feb 2021.

Means, Richard. "Henrik Ibsen.” Henrik Ibsen, Aug. 2017, pp. 1-2. EBSCOhost, search.ebscohost.com/login.aspx?direct=true $\& \mathrm{db}=\mathrm{f} 5 \mathrm{~h} \& \mathrm{AN}=15316439$.

Meier, Paul. "Tremor into Action.” American Theatre, 2010. https://www.americantheatre.org/2010/01/01/tremor-into-action/. Accessed 19 Feb. 2021.

Morgan, Michael Keith \& Uniersity of California, Santa Barbara. "Fitzmaurice Voicework: Constructing the Holistic Actor." University of California, Santa Barbara, 2006.

Ørjasæter, Kristin. "Mother, Wife and Role Model: A Contextual Perspective on Feminism in $A$ Doll's House." Ibsen Studies, 5:1, p19-47. https://www.tandfonline.com/doi/citedby/10.1080/15021860510032835?scroll=top\&need Access=true. Accessed 19 Feb. 2021.

Papa, Andrew, Adriano Cabra \& Elisa Gonzales. "Intellectual, Emotional, and Spiritual Approaches to the Fitzmaurice Voicework Focus Line." Voice and Speech Review, 2020. https://www.tandfonline.com/doi/full/10.1080/23268263.2020.1840143. Accessed 19 Feb 2021.

Peterson, M. Jeanne. "The Victorian Governess: Status Incongruence in Family and Society." Victorian Studies, vol. 14, no. 1, 1970, pp. 7-26. JSTOR, www.jstor.org/stable/3826404. Accessed 29 Nov. 2020.

"Railroads of Norway: Bold Engineering in the Land of the Midnight Sun." Railway Wonders of the World, https://www.railwaywondersoftheworld.com/railroads-norway.html. Accessed 29 Nov 2020.

Rodenburg, Patsy. The Actor Speaks: Voice and the Performer. 1st St. Martin's ed., St. Martin's Press, 2000. 
Roe, Frederick W. "Ibsen as a Dramatist." The Sewanee Review, vol. 13, no. 3, 1905, pp. 305318. JSTOR, www.jstor.org/stable/27530705. Accessed 29 Nov. 2020.

Shaw, Bernard. The Quintessence of Ibsenism: Now Completed to the Death of Ibsen. Hill and Wang, 1957.

Skirbekk, Gunnar. "Processes of Modernization in Norway in the 19th Century: 1814-1884. Interplay between Lutheran State Officials and Popular Movements." Multiple Modernities: A Tale of Scandinavian Experiences, The Chinese University of Hong Kong Press, Hong Kong, 2011, pp. 19-44. JSTOR, www.jstor.org/stable/j.ctt1p9wrb1.5. Accessed 29 Nov. 2020.

Stangor, Charles \& Jennifer Walinga. "Putting It All Together: The Nervous System and the Endocrine System." Introduction to Psychology-1 ${ }^{\text {st }}$ Canadian Edition. BCcampus Open Education, https://opentextbc.ca/introductiontopsychology/chapter/3-4-putting-it-alltogether-the-nervous-system-and-the-endocrine-system/. Accessed 19 Feb. 2021.

Templeton, Joan. "Ibsen, Henrik 1828-1906." Encyclopedia of Sex and Gender, edited by Fedwa Malti-Douglas, vol. 2, Macmillan Reference USA, 2007, pp. 751-752. Gale eBooks, https://link.gale.com/apps/doc/CX2896200314/GVRL?u=morg77564\&sid=GVRL\&xid= e0c986eb. Accessed 29 Nov. 2020.

“The Rørosbanen Railway." Visit Norway, https://www.visitnorway.com/plan-your-trip/gettingaround/by-train/vy/sponsor-rorosbanen-railway/. Accessed 29 Nov 2020.

Van der Kolk, Bessel A. The Body Keeps the Score: Brain, Mind, and Body in the Healing of Trauma. Penguin Books, 2015.

Van der Poll, Suze. "Enemy of Society, Hero of the Nation: Henrik Ibsen (1828-1906). Idolizing Authorship: Literary Celebrity and the Construction of Identity, 1800 to the Present. Edited by Gaston Franssen \& Rick Honings. Amsterdam University Press, 2017. JSTOR, www.jstor.org/stable/j.ctt1pk3jp9. Accessed 29 Nov. 2020.

Walchester, Kathryn. Gamle Norge and Nineteenth-Century British Women Travellers in Norway. Anthem Press, 2014. JSTOR, www.jstor.org/stable/j.ctt1gxp902. Accessed 29 Nov. 2020. 